OPEN ACCESS

Edited by:

Christian Grenz,

UMR 7294 Institut Méditerranéen

d'océanographie (MIO), France

Reviewed by:

Kimberlee Baldry,

University of Tasmania, Australia

Jennifer Joan Verduin,

Murdoch University, Australia

*Correspondence:

Wen-Chen Chou

wcchou@mail.ntou.edu.tw

Specialty section:

This article was submitted to Marine Ecosystem Ecology,

a section of the journal

Frontiers in Marine Science

Received: 31 May 2021 Accepted: 11 October 2021 Published: 11 November 2021

Citation:

Chou W-C, Fan L-F, Yang C-C Chen $Y-H$, Hung $C-C$, Huang $W-J$,

Shih $Y-Y$, Soong $K$, Tseng $H-C$,

Gong G-C, Chen $\mathrm{H}-\mathrm{Y}$ and Su C-K

(2021) A Unique Diel Pattern

in Carbonate Chemistry

in the Seagrass Meadows of Dongsha

Island: The Enhancement

of Metabolic Carbonate Dissolution

in a Semienclosed Lagoon.

Front. Mar. Sci. 8:717685.

doi: 10.3389/fmars.2021.717685

\section{A Unique Diel Pattern in Carbonate Chemistry in the Seagrass Meadows of Dongsha Island: The Enhancement of Metabolic Carbonate Dissolution in a Semienclosed Lagoon}

\author{
Wen-Chen Chou ${ }^{1,2 *}$, Lan-Feng Fan', Chang-Chang Yang', Ying-Hsuan Chen', \\ Chin-Chang Hung ${ }^{3}$, Wei-Jen Huang ${ }^{3}$, Yung-Yen Shih ${ }^{3,4}$, Keryea Soong ${ }^{3}$, \\ Hsiao-Chun Tseng ${ }^{1}$, Gwo-Ching Gong',2, Hung-Yu Chen ${ }^{5}$ and Cheng-Kuan Su ${ }^{6}$ \\ ${ }^{1}$ Institute of Marine Environment and Ecology, National Taiwan Ocean University, Keelung, Taiwan, ${ }^{2}$ Center of Excellence \\ for the Oceans, National Taiwan Ocean University, Keelung, Taiwan, ${ }^{3}$ Department of Oceanography, National Sun Yat-sen \\ University, Kaohsiung, Taiwan, ${ }^{4}$ Department of Applied Science, R.O.C. Naval Academy, Kaohsiung, Taiwan, ${ }^{5}$ Department \\ of Marine Environmental Informatics, National Taiwan Ocean University, Keelung, Taiwan, ${ }^{6}$ Department of Chemistry, \\ National Chung Hsing University, Taichung, Taiwan
}

In contrast to other seagrass meadows where seawater carbonate chemistry generally shows strong diel variations with higher $\mathrm{pH}$ but lower partial pressure of $\mathrm{CO}_{2} \quad\left(\mathrm{pCO}_{2}\right)$ during the daytime and lower $\mathrm{pH}$ but higher $\mathrm{pCO}_{2}$ during nighttime due to the alternation in photosynthesis and respiration, the seagrass meadows of the inner lagoon (IL) on Dongsha Island had a unique diel pattern with extremely high $\mathrm{pH}$ and low $\mathrm{pCO}_{2}$ across a diel cycle. We suggest that this distinct diel pattern in $\mathrm{pH}$ and $\mathrm{pCO}_{2}$ could be associated with the enhancement of total alkalinity (TA) production coupled to carbonate sediment dissolution in a semienclosed lagoon. The confinement of the IL may hamper water exchange and seagrass detritus export to the adjacent open ocean, which may result in higher organic matter loading to the sediments, and longer residence time of the water in the IL, accompanied by microbial respiration (both aerobic and anaerobic) that may reduce carbonate saturation level to drive carbonate dissolution and thus TA elevation, thereby forming such a unique diel pattern in carbonate chemistry. This finding further highlights the importance of considering TA production through metabolic carbonate dissolution when evaluating the potential of coastal blue carbon ecosystems to buffer ocean acidification and to absorb atmospheric $\mathrm{CO}_{2}$, in particular in a semienclosed setting.

Keywords: alkalinity production, carbonate dissolution, seagrass, Dongsha Island, blue carbon, ocean acidification

\section{INTRODUCTION}

As one of the most productive ecosystems on Earth, seagrass meadows have been recognized for their important role in "blue carbon" storage (Duarte et al., 2010; Fourqurean et al., 2012). In addition to the significant carbon sequestration potential of seagrass meadows, previous studies have shown that the high level of seagrass primary productivity may alter seawater carbonate 
chemistry by taking up a large amount of carbon dioxide (Frankignoulle and Distèche, 1984; Gattuso et al., 1998), and some recent studies have further proposed that seagrass meadows have the potential to mitigate ocean acidification (OA) induced by rising atmospheric $\mathrm{CO}_{2}$ (Manzello et al., 2012; Unsworth et al., 2012; Pacella et al., 2018).

Carbonate chemistry dynamics in the water column of seagrass meadows is well known to be driven by a variety of metabolic activities, including plant photosynthesis/respiration (Gattuso et al., 1998; Semesi et al., 2009), carbonate formation/dissolution (Barrón et al., 2006; Burdige et al., 2008; Howard et al., 2018; Saderne et al., 2019b), benthic metabolism (Berg et al., 2019), and hydrodynamic processes (Ruesink et al., 2015; Baldry et al., 2020). As a result, the carbonate system in the overlying water column of seagrass meadows generally shows large variabilities at diel and tidal time scales as well as seasonal variations (Frankignoulle and Distèche, 1984; Waldbusser and Salisbury, 2014; Cyronak et al., 2018; Saderne et al., 2019a). In fact, several in situ investigations have revealed conflicting evidence as to whether seagrass meadows can buffer against OA. For instance, Challener et al. (2016) found significant diel and seasonal variability in seawater $\mathrm{pH}$ and the saturation state of aragonite $\left(\Omega_{\mathrm{a}}\right)$ in a Florida seagrass meadow; the high $\mathrm{pH}$ and $\Omega_{\mathrm{a}}$ values, which would alleviate OA, were observed during the daytime/growing season due to dissolved inorganic carbon (DIC) uptake, while the low $\mathrm{pH}$ and $\Omega_{\mathrm{a}}$ values, which would exacerbate $\mathrm{OA}$, occurred during the nighttime/decay season due to DIC release. Furthermore, Hendriks et al. (2014) also reported diel $\mathrm{pH}$ changes in Mediterranean seagrass meadows, where the $\mathrm{pH}$ during $47 \%$ of the observation time was lower than the source seawater $\mathrm{pH}$, suggesting a certain period of time when the seagrass meadows could not mitigate OA but exacerbated OA. These surveys clearly demonstrate that the OA buffering potential of seagrass meadows may have considerable temporal variability.

Our previous study documented the divergent behaviors in carbonate chemistry in two hydrodynamically contrasting seagrass meadows at Dongsha Island in the northern South China Sea (NSCS) during a 6-day survey in August 2015 (Figure 1), in which higher $\mathrm{pH}$ and total alkalinity (TA) but lower partial pressure of $\mathrm{CO}_{2}\left(p \mathrm{CO}_{2}\right)$ were observed in the semi-enclosed inner lagoon (IL) than on the open north shore, and a unexpected diel pattern with an extremely high $\mathrm{pH}$ and $\mathrm{pCO}_{2}$ across a diurnal cycle was found in the sheltered IL (Chou et al., 2018). In this study, we revisited the same sites to examine whether the divergent behaviors in carbonate chemistry between two sites and the distinct diel pattern in the sheltered IL would occur repeatedly in all seasons. More importantly, recent studies have suggested that sedimentary TA production and export may represent an important but overlooked sink in blue carbon ecosystems (Sippo et al., 2016; Maher et al., 2018; Saderne et al., 2020; Reithmaier et al., 2021). Thus, we also collected sediment cores and porewater samples to examine the potential role of TA production coupled to carbonate dissolution in regulating the carbonate dynamics in the overlying waters. We found that the confinement of the semienclosed IL may provide an ideal scenario for metabolic carbonate dissolution in sediments and thus TA production, including high organic matter (OM) content, low sediment permeability and a long porewater residence time, thus distinguishing the seagrass meadows in the IL on Dongsha Island from those in the open environment.

\section{MATERIALS AND METHODS}

\section{Study Sites}

The study sites were the same as those in our previous work and have been comprehensively described in Chou et al. (2018). Briefly, the Dongsha Atoll is a circular coral reef located in the NSCS, and Dongsha Island is situated on the western margin of the atoll. A semienclosed IL occupies the central part of Dongsha Island (Figure 1). Two hydrodynamically contrasting seagrass meadows were chosen so that their characteristics in seawater carbonate chemistry could be compared. One meadow is located on the northern shore (NS), where water can freely exchange with the adjacent open ocean; the other is situated in the IL, where water exchange is largely hampered due to confinement by a sand barrier. Both sites are multispecies seagrass meadows with the same dominant species (Thalassia hemprichii and Cymodocea rotundata). Previous study have revealed that the average total seagrass biomass, seagrass cover, canopy height, and shoot density were $949.4 \pm 62.1$ and $827.4 \pm 74.8\left(\mathrm{~g} \mathrm{DW} \mathrm{m}^{-2}\right)$, $81.91 \pm 2.13$ and $85.14 \pm 6.33(\%), 22.36 \pm 1.22$ and $20.62 \pm 1.52$ $(\mathrm{cm})$, and $2677 \pm 485$ and $2920 \pm 639\left(\right.$ shoots $\left.\mathrm{m}^{-2}\right)$ on the NS and in the IL, respectively, based on four surveys conducted in April, August, October 2010, and February 2011 (Lee et al., 2015).

\section{Sampling and Carbonate Chemistry Analysis}

This study was conducted in four different seasons between 2016 and 2019. During each investigation, a multiparameter sonde (Ocean Seven 316 Plus CTD; Idronaut S.r.I, Brugherio, Italy) attached to a frame was deployed within the seagrass canopy $0.1 \mathrm{~m}$ above the sediment at each site to record temperature, salinity, water depth, and dissolved oxygen (DO). The CTD mooring were from January 2 to 7 and from January 7 to 12, 2016 in winter, and from November 16 to 19 and from November 11 to 19 with an interruption between November 14 and 16, 2016 in autumn at the NS and IL sites, respectively. In spring, the CTD mooring was from April 6 to 18, 2018 at the both sites, and with an interruption between April 7 and 10 at the NS site. Furthermore, probably due to the low water level with periods of emersions, a malfunction of the CTD caused a missing of temperature and salinity data at the IL site during the spring deployment. And so, the temperature, salinity and DO data were disregarded for the NS site when water level less than $15 \mathrm{~cm}$. In summer, the CTD mooring was from June 28 to July 3, 2019 at the two sites.

Discrete seawater samplings were conducted in January 2016 (1/1-12; winter), November 2016 (11/11-13; autumn), April 2018 (4/12-18; spring), and June-July 2019 (6/28-7/3; summer). The water depth at the IL and NS sampling sites was approximately 0.5 to $1 \mathrm{~m}$. During these sampling periods, discrete surface seawater samples for carbonate chemistry analysis were 


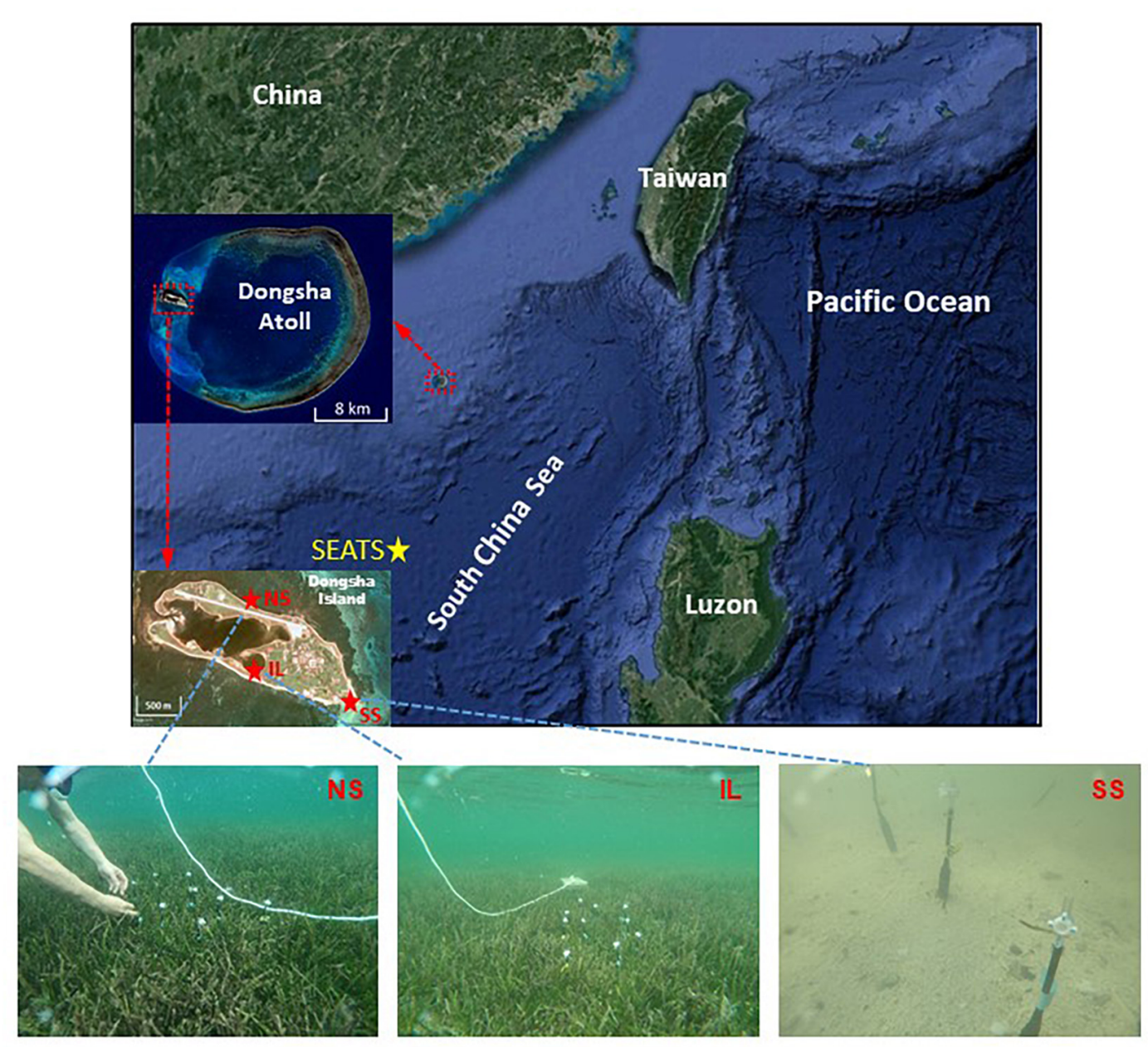

FIGURE 1 | Map showing the locations of Dongsha Atoll, Dongsha Island, and the sampling sites around Dongsha Island (upper panels) and photos showing the porewater sampling sites on the northern shore (NS), in the inner lagoon (IL), and on the southern shore (SS) (lower panels). The yellow asterisk indicating the location of the SouthEast Asian Time-series Study (SEATS).

taken at approximately 6:00 a.m., 12:00 a.m., and 18:00 p.m. every day, using a 9-L Nalgene ${ }^{\mathrm{TM}}$ HDPE carboy. The water samples were first passed through a $100-\mu \mathrm{M}$ nylon mesh, and then transferred into $350-\mathrm{mL}$ pre-cleaned borosilicate bottles thoroughly flushed with sample with extensive overflow $(>200 \mathrm{~mL})$. These samples were subsequently injected with $100 \mu \mathrm{L}$ of saturated $\mathrm{HgCl}_{2}$ solution and stored at room temperature in darkness until they were analyzed in a shorebased laboratory. Measurements of TA, DIC, and $\mathrm{pH}$ followed the standard operating procedures described in Dickson et al. (2007), and the procedures were consistent with those used in our previous studies (Chou et al., 2018, 2020). Briefly, DIC and TA were determined using the non-dispersive infrared method on a DIC analyzer (AS-C3, Apollo SciTech) and Gran titration on an automatic TA titrator (AS-ALK2, Apollo SciTech), respectively, and both measurements had accuracies and precisions of $0.2 \%$ or better. The $\mathrm{pH}$ was spectrophotometrically measured at $25^{\circ} \mathrm{C}$ with a precision of 0.005 (Chou et al., 2016). The $p \mathrm{CO}_{2}$ and $\Omega_{\mathrm{a}}$ were calculated from the measured DIC and TA data using the Excel macro CO2SYS version 2.1 (Pelletier et al., 2011). Furthermore, in order to examine the effect of temperature on $\mathrm{pH}$ and $\mathrm{pCO}_{2}$ variations, the measured $\mathrm{pH}$ at $25^{\circ} \mathrm{C}\left(\mathrm{pH}_{25}\right)$ was corrected to in situ temperature $\left(\mathrm{pH}_{\text {in situ }}\right)$, and the $p \mathrm{CO}_{2}$ was calculated at both in situ temperature $\left(p \mathrm{CO}_{2 \text { in situ }}\right)$ and the average temperature of $26.2^{\circ} \mathrm{C}\left(\mathrm{TpCO}_{2}\right)$. Similarly, TA and DIC were normalized to the average salinity of 35.6 (NTA $($ NDIC $)=$ TA $($ DIC $) \times 35.6 /$ salinity $)$ to remove the effect of evaporation/precipitation on their variations (Chou et al., 2018).

\section{Sediment Cores and Porewater Samplings and Grain Size, Total Carbon and Nitrogen, and Calcium Ion Analyses}

Sediment cores and porewater samples were collected in the summer of 2019 at the IL, NS, and another unvegetated site located on the southern shore (SS; Figure 1), which served as a reference site. Because of the difficulty inherent in collecting a core of sandy sediments (Drupp et al., 2016), only one $25-\mathrm{cm}$ 
push core from the IL, one $16.5-\mathrm{cm}$ push core from the NS and one $18-\mathrm{cm}$ push core from the SS were collected. The IL, NS, and SS cores were sectioned into 5, 3, and 3 layers $\sim 5$ to $6 \mathrm{~cm}$ thick, respectively, which were stored in a $-20^{\circ} \mathrm{C}$ freezer until subsequent analysis. Grain size distribution was determined via wet-sieving through the Wentworth series of screens with mesh openings from $1.0 \mathrm{~mm}$ to $63 \mu \mathrm{m}$ (Folk, 1966). Median grain size was calculated using the GRADISTAT software (Blott and Pye, 2001). Each core section was measured for total carbon (TC) and total nitrogen (TN) contents using an elemental analyzer (Elementar, Vario EL-III, Germany), according to Hung and Gong (2010).

Porewater samples were collected using porewater wells and modified from Falter and Sansone (2000). A total volume of $25 \mathrm{ml}$ porewater was extracted from each well at 2, 4, 6, 8, 12,16 , and $20 \mathrm{~cm}$ sediment depths using a Luer-Lok syringe. The sampling procedure and sample preservation of porewater followed the methods in Kindeberg et al. (2020). In addition to carbon chemistry parameters (TA, DIC, and $\mathrm{pH}$ ), the calcium ion concentration of the porewater was determined using an ICP-MS system (Agilent $7700 \times$, Agilent Technologies) based on that in Su and Ho (2019).

\section{Statistical Analysis}

Due to the variance changes across seasons and sites, a Wilcox's robust ANOVA (WR-ANOVA) was chosen to account for heteroscedasticity among habitat groups. Tests between medians were chosen rather than between means, as seagrass habitats displayed skewed carbonate chemistry observations (Baldry et al., 2020). Differences in the medians of $\mathrm{pH}_{25}, \mathrm{pH}_{\text {in situ }}, \mathrm{pCO}_{2 \text { in situ }}$, Tp $\mathrm{CO}_{2}$, DIC, normalized DIC (NDIC), TA, and normalized TA (NTA) between the IL and NS sites in each season were assessed using a WR-ANOVA that was implemented by the function "med1way" of the R package "WRS2" (Mair and Wilcox, 2020). All statistical tests were performed using R software v4.1.1 (R Core Team, 2021) with a 95\% confidence level.

\section{RESULTS}

\section{Temporal Variations in Temperature, Salinity, Water Depth, and Dissolved Oxygen}

The mean $( \pm S D)$ temperature during the sampling period was $23.6 \pm 1.8,27.1 \pm 0.8,26.4 \pm 2.1$, and $31.1 \pm 1.1^{\circ} \mathrm{C}$ at the NS site (red symbols in Figures 2A-D), and $21.7 \pm 1.4,26.3 \pm 1.1$, not determined (n.d.), and $31.4 \pm 1.7^{\circ} \mathrm{C}$ at the IL site (blue symbols in Figures 2A-D) in winter, autumn, spring and summer, respectively. Not surprisingly, the highest average temperature was in summer, and the lowest was in winter, and the average temperature in spring and autumn was in the intermediate range. The mean $( \pm S D)$ salinity was $34.6 \pm 0.3,33.8 \pm 0.5,33.8 \pm 0.4$, and $33.8 \pm 0.5$ at the NS site (red symbols in Figures $2 \mathbf{E}-\mathbf{H}$ ), and $36.8 \pm 0.3,34.7 \pm 0.3$, n.d., and $34.9 \pm 0.6$ at the IL site (blue symbols in Figures 2E-H) in winter, autumn, spring, and summer, respectively. The highest average salinity was in winter, but the average salinity did not display remarkable difference among the other seasons at the both sites. Generally, the average salinity at the IL site was higher than the NS site in all seasons. The mean $( \pm S D)$ water depth was $0.71 \pm 0.17,0.62 \pm 0.37$, $0.37 \pm 0.18$, and $1.07 \pm 0.29$ at the NS site (red symbols in Figures 2I-L), and $0.48 \pm 0.11,0.70 \pm 0.20,0.24 \pm 0.10$, and $0.50 \pm 0.20$ at the IL site (blue symbols in Figures 2I-L) in winter, autumn, spring and summer, respectively. The lowest average water depth was in spring at the both sites, and the highest average water depth was in autumn and summer at the IL and NS sites, respectively. Overall, the water depth showed a larger daily variation range at the NS site than the IL site in all seasons. The mean $( \pm S D)$ DO saturation during the complete recording period was $93 \pm 33,112 \pm 37,83 \pm 42$, and $66 \pm 33$ at the NS site (red symbols in Figures $2 \mathbf{M}-\mathbf{P}$ ), and $77 \pm 12,82 \pm 13,69 \pm 21$, and $59 \pm 19$ at the IL site (blue symbols in Figures $2 \mathbf{M}-\mathbf{P}$ ) in winter, autumn, spring, and summer, respectively. The highest and lowest average DO saturation was in autumn and summer, respectively, at the both sites. Similar to the water depth, DO saturation generally showed a larger daily variation range at the NS site than the IL site in all seasons.

\section{Temporal Variations in Carbonate Chemistry}

The seasonal daily variations in $\mathrm{pH}_{25}, \mathrm{pH}_{\text {in situ }}, \mathrm{pCO}_{2 \text { in situ }}$, $\mathrm{T}_{p} \mathrm{CO}_{2}, \mathrm{TA}, \mathrm{NTA}, \mathrm{DIC}$, and NDIC at the NS and IL sites are shown in Figure 3, and the means $( \pm S D)$ and the statistical analysis results on the difference in the medians of these parameters between the two sites are given in Table 1. Despite the notable daily variations in temperature and salinity, the temperature corrected $\mathrm{pH}\left(\mathrm{pH}_{25}\right)$ and $\mathrm{pCO}_{2}\left(\mathrm{~T} p \mathrm{CO}_{2}\right)$ generally displayed the similar daily variation pattern as those in in situ condition. Likewise, the salinity normalized NTA and NDIC also showed the parallel daily variation pattern as those in in situ condition.

At the NS site (red squares), $\mathrm{pH}_{25}, \mathrm{~T} p \mathrm{CO}_{2}$ and NDIC showed distinct daily excursions in all seasons, which generally followed the daily pattern of photosynthesis and respiration, as evidenced by the DO data shown in Figures 2M-P: $\mathrm{pH}_{25}$ increased, but $\mathrm{T} p \mathrm{CO}_{2}$ and NDIC decreased during the day; and $\mathrm{pH}_{25}$ decreased, but $\mathrm{T}_{p} \mathrm{CO}_{2}$ and NDIC increased during the night due to the daytime photosynthetic $\mathrm{CO}_{2}$ uptake and nighttime respiratory $\mathrm{CO}_{2}$ release. In contrast, NTA did not show a clear daily cycle in all seasons, except that a weak daily pattern occurred in winter, with an increase at night but a decrease during the day (Figure $3 \mathbf{M}$ ). At the IL site (blue circle), similar daily variability was found for $\mathrm{pH}_{25}, \mathrm{~T} p \mathrm{CO}_{2}$, and NDIC; however, the amplitudes of variation were generally much smaller than those at the NS site: the mean $( \pm \mathrm{SD})$ daily variation ranges in $\mathrm{pH}_{25}$ $\left(\mathrm{pH}_{25}\right.$ at $18: 00-\mathrm{pH}_{25}$ at $\left.06: 00\right)$ for NS vs. IL were $0.58 \pm 0.18$ vs. $0.13 \pm 0.07,0.56 \pm 0.03$ vs. $0.11 \pm 0.04,0.42 \pm 0.16$ vs. $0.05 \pm 0.06$, and $0.30 \pm 0.19$ vs. $0.05 \pm 0.15$; the mean $( \pm S D)$ daily variation ranges in $\mathrm{T} p \mathrm{CO}_{2}\left(\mathrm{~T} p \mathrm{CO}_{2}\right.$ at $18: 00-\mathrm{T} p \mathrm{CO}_{2}$ at 06:00) were $-765 \pm 406$ vs. $-34 \pm 13 \mu$ atm, $-518 \pm 77$ vs. $-58 \pm 12 \mu \mathrm{atm},-249 \pm 164$ vs. $-10 \pm 13 \mu \mathrm{atm}$, and $-313 \pm 272$ vs. $-5 \pm 36 \mu \mathrm{atm}$; and the mean $( \pm \mathrm{SD})$ daily variation range 

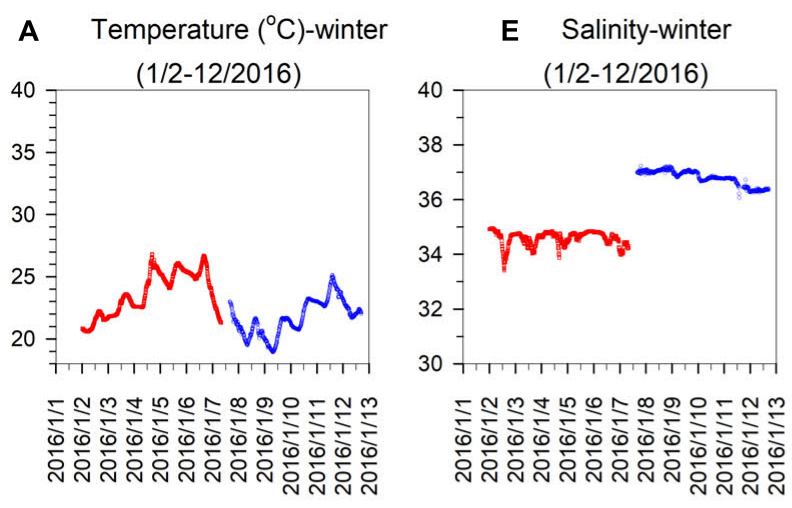

B Temperature $\left({ }^{\circ} \mathrm{C}\right)$-autumn

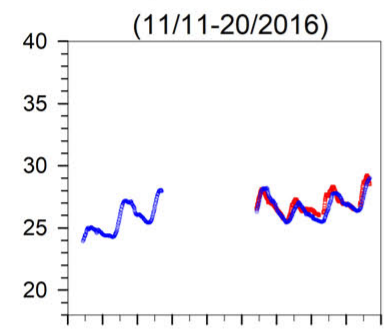

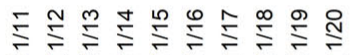

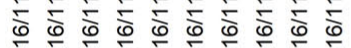

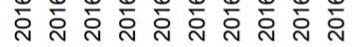
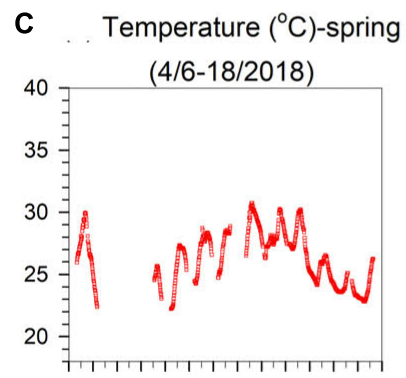

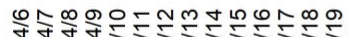

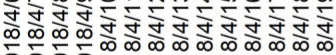

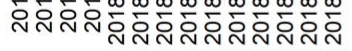

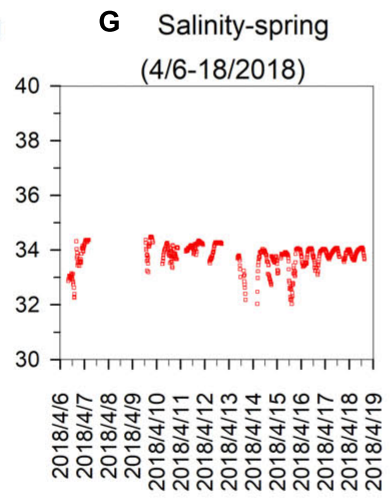

F Salinity-autumn $(11 / 11-20 / 2016)$

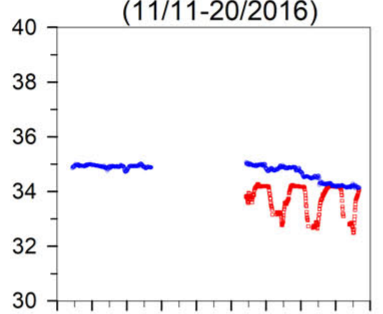

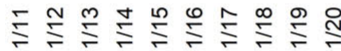

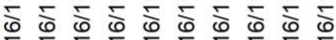

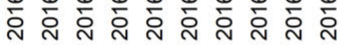

K Water depth (m)-spring

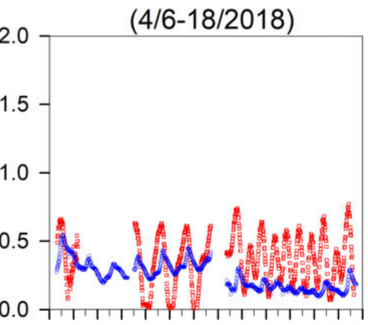

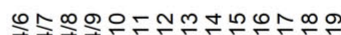
m.5

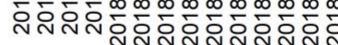

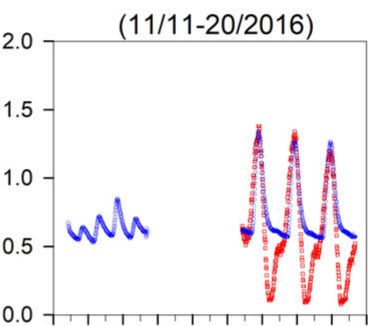

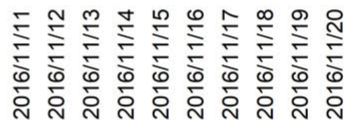
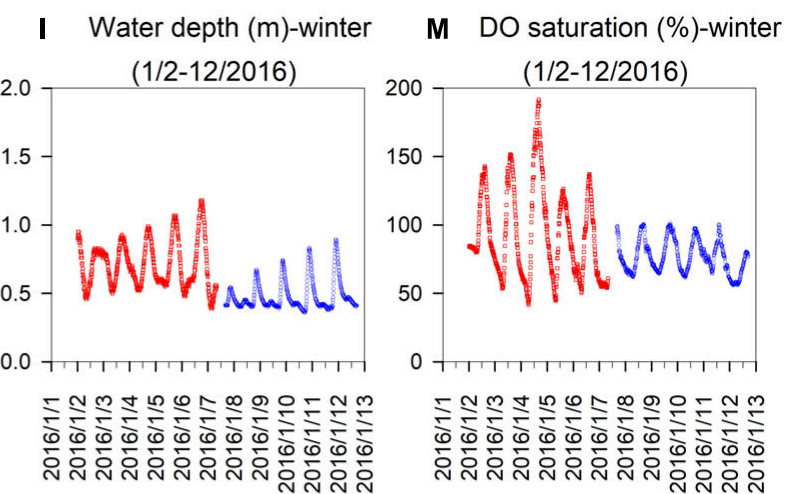

N DO saturation (\%)-autumn

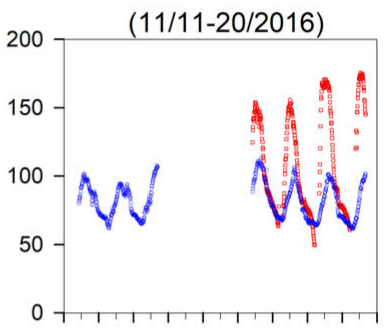

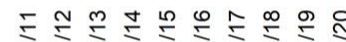

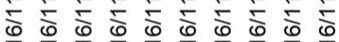

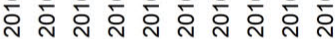

O DO saturation (\%)-spring
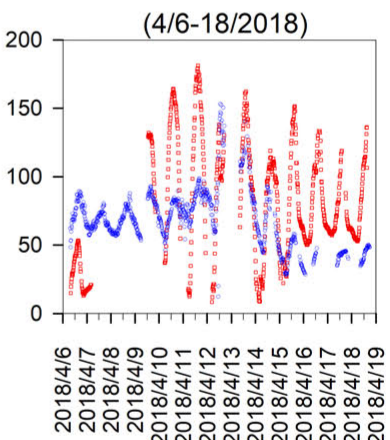

L Water depth (m)-summer $(6 / 28-7 / 3 / 2019)$
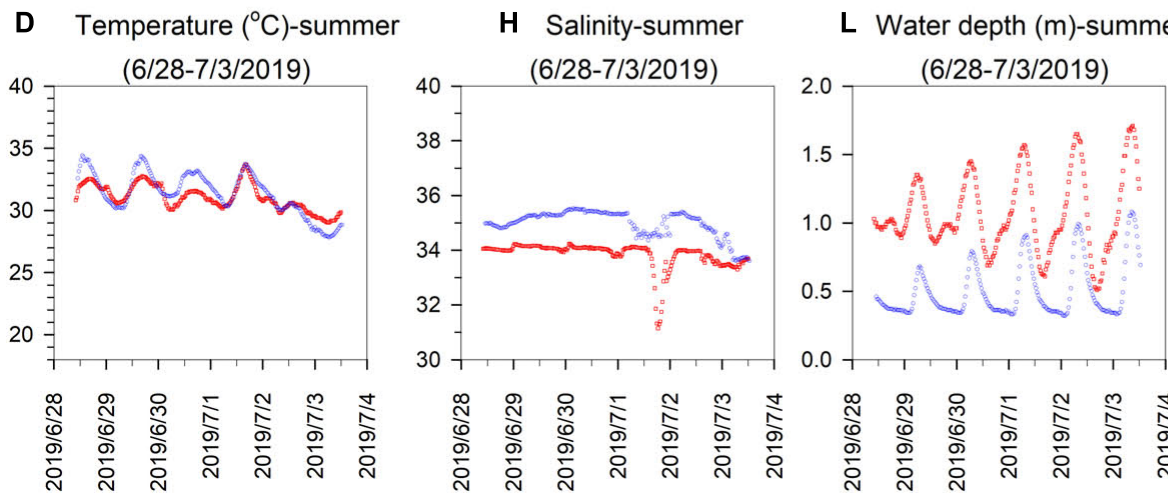

P DO saturation (\%)-summer

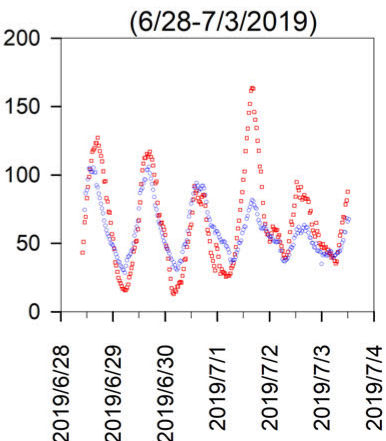

FIGURE 2 | Seasonal time-series observations of (A-D) temperature, (E-H) salinity, (I-L) water depth, and (M-P) DO saturation in the inner lagoon (IL, blue circles) and on the northern shore (NS, red squares) of Dongsha Island. 
in NDIC (NDIC at 18:00-NDIC at 06:00) were $-503 \pm 191$ vs. $-144 \pm 63 \mu \mathrm{mol} \mathrm{kg}{ }^{-1},-390 \pm 7$ vs. $-122 \pm 32 \mu \mathrm{mol} \mathrm{kg}^{-1}$, $-257 \pm 255$ vs. $-141 \pm 118 \mu \mathrm{mol} \mathrm{kg}{ }^{-1}$, and $-115 \pm 154$ vs. $-107 \pm 181 \mu \mathrm{mol} \mathrm{kg} \mathrm{kg}^{-1}$ in winter, autumn, spring and summer, respectively. The potential mechanism causing the smaller amplitudes of daily variations in $\mathrm{pH}_{25}, \mathrm{TpCO}_{2}$ and NDIC will be further examined in "Discussion" section.

The horizontal bands superimposed on Figures 3A-D,I-P represent the typical seasonal variation ranges of $\mathrm{pH}, \mathrm{DIC}$, and TA, respectively, in the adjacent NSCS, which were collected from the SouthEast Asian Time-series Study (SEATS) station at $18^{\circ} \mathrm{N}$ and $116^{\circ} \mathrm{E}$ (Figure 1) during 19 cruises between 1999 and 2003 (Chou et al., 2005; Tseng et al., 2007). The horizontal dashed lines shown in Figures E-H denote the atmospheric $p \mathrm{CO}_{2}$ (400 $\mu \mathrm{atm})$. As shown, at the NS site, the $\mathrm{pH}_{25}$ was generally higher than the typical ranges in the adjacent NSCS from midday to midnight; however, the $\mathrm{pH}_{25}$ was lower from midnight to midday in all seasons, and the opposite pattern was found for NDIC. Similarly, TpCO $\mathrm{CO}_{2}$ was lower than the atmospheric $p \mathrm{CO}_{2}$ from midday to midnight, while it was higher from midnight to midday in all seasons, except in spring, when $\mathrm{T} p \mathrm{CO}_{2}$ across a daily cycle was almost always lower than the atmospheric $p \mathrm{CO}_{2}$. NTA across a daily cycle was generally higher than the typical range in the adjacent NSCS, except in summer, when NTA varied within the typical range. In contrast, at the IL site, the $\mathrm{pH}_{25}$ across a daily cycle was higher than the typical range in the adjacent NSCS, while the $\mathrm{T} p \mathrm{CO}_{2}$ across a daily cycle was lower than the atmospheric $\mathrm{pCO}_{2}$ in all seasons, suggesting that $\mathrm{OA}$ buffering and atmospheric $\mathrm{CO}_{2}$ absorbing capacities for the seagrass meadows in the IL on Dongsha Island existed in all seasons. Furthermore, NDIC across a daily cycle was generally lower than the typical range in the adjacent NSCS, except in fall when NDIC was higher. In contrast, NTA across a daily cycle was almost always higher than the typical TA range in the adjacent NSCS in all seasons.

\section{Porewater Carbonate Chemistry and Calcium Ion Concentration}

The vertical porewater profiles of the carbonate parameters and calcium ion concentrations at the SS, NS, and IL sites are shown in Figures $\mathbf{4 A - F}$. Overall, porewater DIC, TA, and $p \mathrm{CO}_{2}$ profiles showed an increasing trend with sediment depth, and values were generally greater in the porewater than in the overlying water column at all sites. In contrast, $\mathrm{pH}$ and $\Omega_{\mathrm{a}}$ revealed a decreasing trend, and values were lower in the porewater than in the overlying water column. Nevertheless, the vertical gradients of the carbonate parameters differed strikingly among the different sites. The sharpest vertical gradients of porewater carbonate parameters were found at the IL site, where the average depth-integrated changes in DIC, TA, $p \mathrm{CO}_{2}, \mathrm{pH}$, and $\Omega_{\mathrm{a}}$ relative to the sediment-water interface (SWI) were $+3502 \pm 1218 \mu \mathrm{M},+1791 \pm 865 \mu \mathrm{M},+27457 \pm 15775 \mu \mathrm{atm}$, $-2.31 \pm 0.18 \mathrm{pH}$ units, and $-12.29 \pm 0.73$, respectively, and the smallest vertical gradients of carbonate parameters were observed at the unvegetated SS site, where the average depth-integrated changes in DIC, TA, $p \mathrm{CO}_{2}, \mathrm{pH}$, and $\Omega_{\mathrm{a}}$ were $+77 \pm 23 \mu \mathrm{M}$, $+27 \pm 28 \mu \mathrm{M},+151 \pm 75 \mu \mathrm{atm},-0.18 \pm 0.15 \mathrm{pH}$ units, and $-0.51 \pm 0.31$, respectively. The vertical profiles of the carbonate parameters at the NS site were closer in magnitude to those at the unvegetated SS site than those at the IL site, where the average depth-integrated changes in DIC, TA, $p \mathrm{CO}_{2}, \mathrm{pH}$, and $\Omega_{\mathrm{a}}$ were $+386 \pm 114 \mu \mathrm{M},+91 \pm 67 \mu \mathrm{M}$, $+1456 \pm 627 \mu \mathrm{atm},-0.44 \pm 0.09 \mathrm{pH}$ units, and $-2.90 \pm 0.57$, respectively. Furthermore, it is worth noting that porewater below $2 \mathrm{~cm}$ at the IL site was generally undersaturated with respect to aragonite $\left(\Omega_{\mathrm{a}}<1\right.$; except at $\left.12 \mathrm{~cm}\right)$, while porewater remained supersaturated $\left(\Omega_{\mathrm{a}}>1\right)$ throughout the entire profiles at the NS and SS sites (Figure 4E).

The vertical profiles of calcium ion concentration in porewaters also differed markedly among the different sites. The calcium ion concentration remained fairly constant at $9.5-10 \mathrm{mM}$ throughout the entire profile at the SS and NS sites, while it gradually increased from the SWI to a maximum of $13.1 \mathrm{mM}$ at $12 \mathrm{~cm}$ and then decreased to $20 \mathrm{~cm}$ at the IL site. Similar to those of the carbonate parameters, the average depth-integrated change in calcium ion concentration at the IL site $(+0.76 \pm 0.84 \mathrm{mM})$ was noticeably higher than those at the NS $(+0.23 \pm 0.06 \mathrm{mM})$ and SS $(+0.17 \pm 0.17 \mathrm{mM})$ sites.

\section{Median Grain Size, Total Carbon, and Total Nitrogen in Sediments}

The vertical distributions of MGS, TC, and TN in the sediments at the SS, NS, and IL sites are shown in Figures 4G-I. Similar to the results of the porewater, the MGS, TC, and TN in the sediments also revealed considerable difference among the different sites. The coarsest grain size was found at the unvegetated SS site (MGS ranging from 800 to $1000 \mu \mathrm{m}$ ), followed by that at the NS site (MGS ranging from 400 to $600 \mu \mathrm{m}$ ), and the finest grain size was observed in the top $12.5 \mathrm{~cm}$ layer at the IL site (MGS ranging from 200 to $400 \mu \mathrm{m})$. TC and TN showed the highest contents at the IL site, with a mean of 17.1 and $0.82 \mathrm{wt} \%$, respectively. At the unvegetated SS site, TC and TN remained relatively constant throughout the core and had the lowest contents, with a mean of 12.8 and $0.01 \%$, respectively. The TC and TN contents at the NS site were closer in magnitude to those at the SS site than those at the IL site, with a mean of 14.1 and $0.04 \mathrm{wt} \%$, respectively.

\section{DISCUSSION}

\section{The Differences in pH and Partial Pressure of $\mathrm{CO}_{2}$ Between the Northern Shore and Inner Lagoon Sites}

In terms of carbonate chemistry, two striking differences between the NS and IL sites can be clearly seen in Figures $\mathbf{3 A - H}$. First, $\mathrm{pH}$ was generally higher, while $p \mathrm{CO}_{2}$ was lower at the IL sites than those at the NS site (noting that due to the smaller sampling numbers and larger variations, the medians of $\mathrm{pH}$ in autumn and the medians of $p \mathrm{CO}_{2}$ in winter and autumn did not show significant difference between the two sites according to a WR-ANOVA analysis, Table 1). Second, the amplitude of daily variations in $\mathrm{pH}$ and $p \mathrm{CO}_{2}$ at the IL site were smaller than the NS site. Because the temperature-corrected $\mathrm{pH}$ and $p \mathrm{CO}_{2}\left(\mathrm{pH}_{25}\right.$ and $\mathrm{Tp} \mathrm{CO}_{2}$ ) displayed the similar patterns (Figures $\mathbf{3 A}-\mathbf{H}$ ) and 


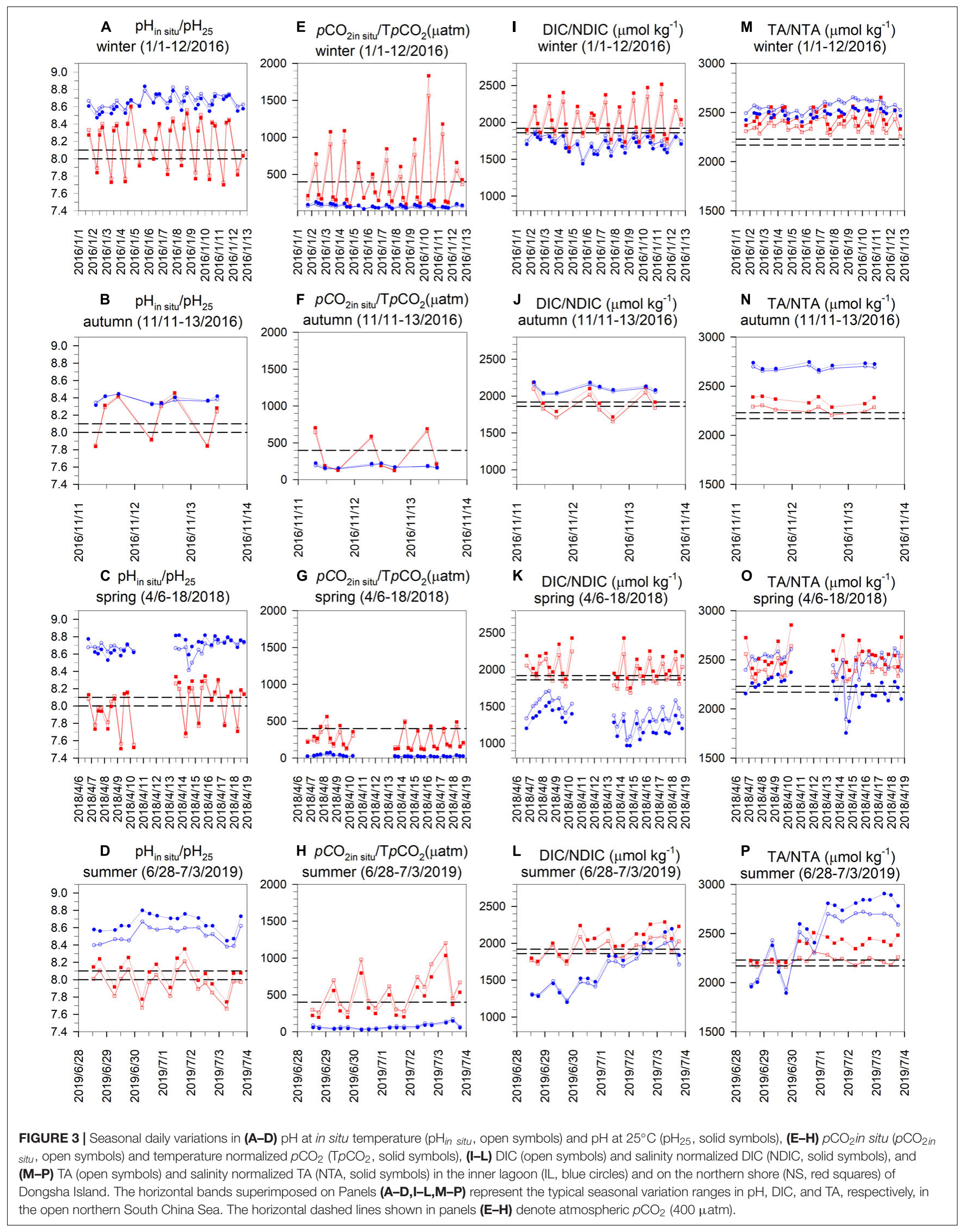



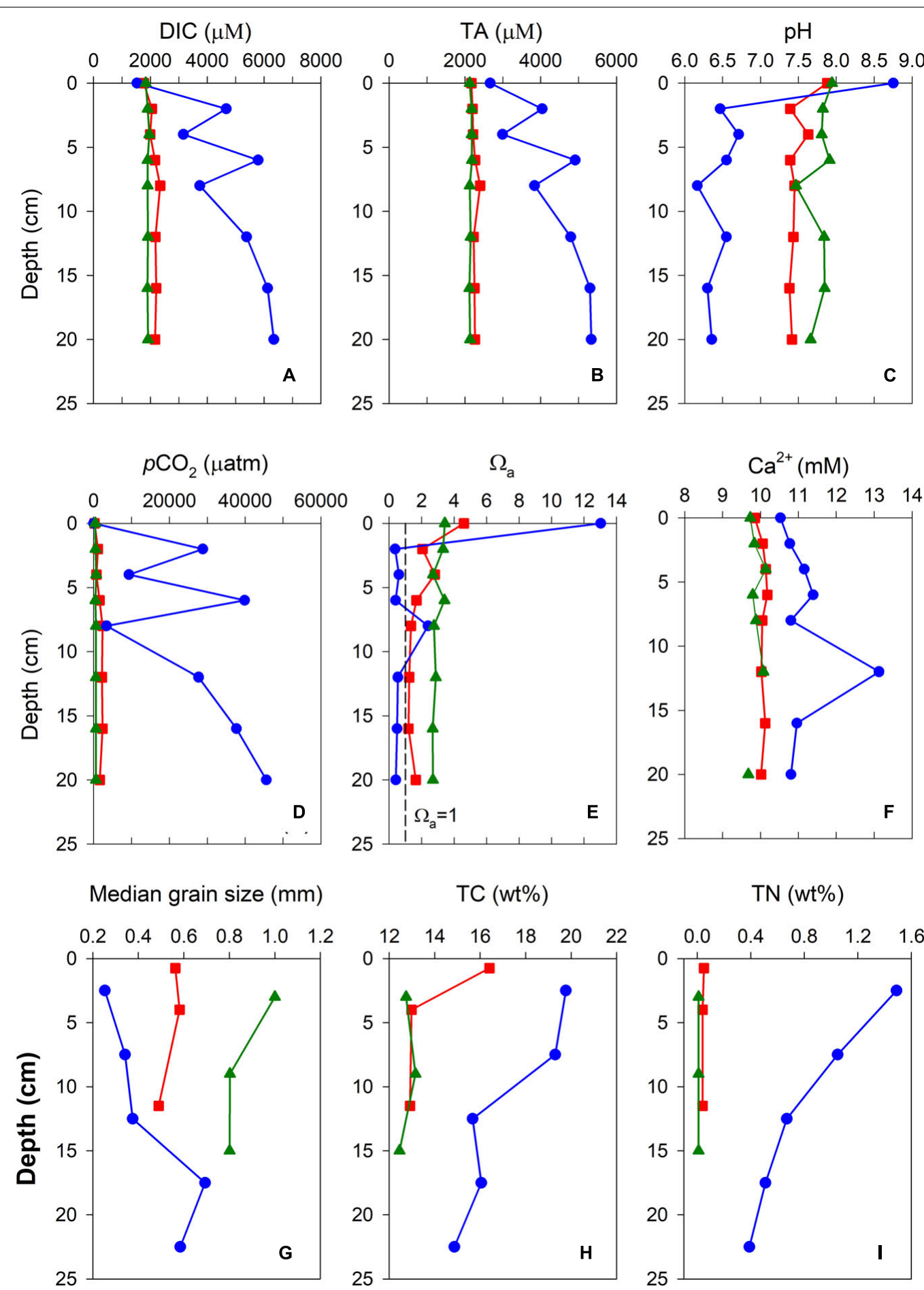

$\mathrm{TN}(\mathrm{wt} \%)$

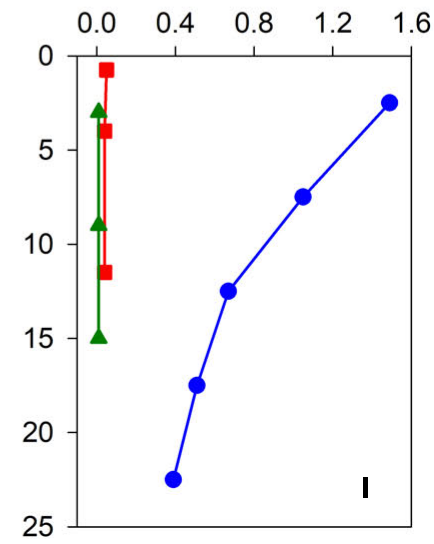

FIGURE 4 | Vertical porewater profiles of (A) DIC, (B) TA, (C) $p \mathrm{CO}_{2}$, (D) pH, (E) $\Omega_{a}$, and (F) Ca ${ }^{2+}$, and vertical distributions of (G) median grain size, (H) total carbon, and (I) total nitrogen in the sediment cores collected on the northern shore (NS, red squares), on the southern shore (SS, green triangles), and in the inner lagoon (IL, blue circles) of Dongsha Island.

the NS and IL sites exhibited similar temperatures in both autumn and summer (Figures 2B,D), temperature effect could not explain the observed different behaviors in $\mathrm{pH}$ and $p \mathrm{CO}_{2}$ between the two sites.
Previous studies have indicated that hydrodynamics is of major importance in seagrass biology, ecology, and ecophysiology (Koch, 1994; Koch et al., 2006). Unfortunately, with the present dataset we cannot clearly quantify the influence 
TABLE 1 | A summary of the mean \pm standard deviation of surface seawater $\mathrm{pH}_{\text {in situ }}, \mathrm{pH}_{25}, \mathrm{pCO}_{2 \text { in situ }}, \mathrm{T} \mathrm{CO}_{2}, \mathrm{TA}, \mathrm{NTA}, \mathrm{DIC}$, and NDIC along with number of samples (n) at the inner lagoon (IL) and the northern shore (NS) sites in four different seasons.

\begin{tabular}{|c|c|c|c|c|c|}
\hline & Season & IL & NS & $n$ & $p$-value \\
\hline \multirow[t]{4}{*}{$\mathrm{pH}_{\text {in situ }}$} & Winter & $8.67 \pm 0.07$ & $8.21 \pm 0.27$ & 64 & $<0.01$ \\
\hline & Autumn & $8.37 \pm 0.04$ & $8.16 \pm 0.25$ & 16 & $=0.25$ \\
\hline & Spring & $8.68 \pm 0.08$ & $8.02 \pm 0.22$ & 56 & $<0.01$ \\
\hline & Summer & $8.52 \pm 0.09$ & $7.95 \pm 0.15$ & 34 & $<0.01$ \\
\hline \multirow[t]{4}{*}{$\mathrm{pH}_{25}$} & Winter & $8.63 \pm 0.09$ & $8.18 \pm 0.28$ & 64 & $<0.01$ \\
\hline & Autumn & $8.38 \pm 0.05$ & $8.18 \pm 0.26$ & 16 & $=0.34$ \\
\hline & Spring & $8.70 \pm 0.08$ & $8.03 \pm 0.25$ & 56 & $<0.01$ \\
\hline & Summer & $8.65 \pm 0.10$ & $8.07 \pm 0.17$ & 34 & $<0.01$ \\
\hline \multirow[t]{4}{*}{$\mathrm{pCO}_{2 \text { in situ }}(\mu \mathrm{atm})$} & Winter & $62 \pm 17$ & $374 \pm 357$ & 64 & $=0.12$ \\
\hline & Autumn & $178 \pm 24$ & $343 \pm 238$ & 16 & $=0.63$ \\
\hline & Spring & $27 \pm 10$ & $238 \pm 115$ & 56 & $<0.01$ \\
\hline & Summer & $76 \pm 36$ & $553 \pm 284$ & 34 & $<0.01$ \\
\hline \multirow[t]{4}{*}{$\mathrm{TpCO}_{2}$ ( $\mu$ atm) } & Winter & $75 \pm 23$ & $436 \pm 423$ & 64 & $=0.14$ \\
\hline & Autumn & $187 \pm 30$ & $354 \pm 258$ & 16 & $=0.77$ \\
\hline & Spring & $29 \pm 16$ & $260 \pm 139$ & 56 & $<0.01$ \\
\hline & Summer & $59 \pm 33$ & $443 \pm 247$ & 34 & $<0.01$ \\
\hline \multirow[t]{4}{*}{$\mathrm{DIC}\left(\mu \mathrm{mol} \mathrm{kg}{ }^{-1}\right)$} & Winter & $1741 \pm 96$ & $1962 \pm 221$ & 64 & $<0.05$ \\
\hline & Autumn & $2088 \pm 52$ & $1877 \pm 161$ & 16 & $<0.01$ \\
\hline & Spring & $1417 \pm 165$ & $1946 \pm 163$ & 56 & $<0.01$ \\
\hline & Summer & $1621 \pm 262$ & $1916 \pm 124$ & 34 & $<0.05$ \\
\hline \multirow[t]{4}{*}{$\mathrm{NDIC}\left(\mu \mathrm{mol} \mathrm{kg}{ }^{-1}\right)$} & Winter & $1689 \pm 94$ & $2037 \pm 241$ & 64 & $<0.01$ \\
\hline & Autumn & $2109 \pm 57$ & $1955 \pm 167$ & 16 & $<0.05$ \\
\hline & Spring & $1265 \pm 153$ & $2060 \pm 179$ & 56 & $<0.01$ \\
\hline & Summer & $1679 \pm 317$ & $2042 \pm 176$ & 34 & $<0.05$ \\
\hline \multirow[t]{4}{*}{$\mathrm{TA}\left(\mu \mathrm{mol} \mathrm{kg}{ }^{-1}\right)$} & Winter & $2567 \pm 51$ & $2365 \pm 64$ & 64 & $<0.01$ \\
\hline & Autumn & $2681 \pm 24$ & $2265 \pm 34$ & 16 & $<0.01$ \\
\hline & Spring & $2458 \pm 152$ & $2405 \pm 95$ & 56 & $<0.01$ \\
\hline & Summer & $2461 \pm 281$ & $2219 \pm 43$ & 34 & $<0.01$ \\
\hline \multirow[t]{4}{*}{ NTA $\left(\mu \mathrm{mol} \mathrm{kg}{ }^{-1}\right)$} & Winter & $2490 \pm 37$ & $2455 \pm 83$ & 64 & $=0.12$ \\
\hline & Autumn & $2709 \pm 32$ & $2359 \pm 41$ & 16 & $<0.01$ \\
\hline & Spring & $2192 \pm 139$ & $2546 \pm 121$ & 56 & $<0.01$ \\
\hline & Summer & $2545 \pm 355$ & $2363 \pm 105$ & 34 & $<0.05$ \\
\hline
\end{tabular}

Differences in the medians of these parameters between the $\mathrm{L}$ and NS were assessed using a Wilcox's robust ANOVA. A significance level of 0.05 was used to determine significant statistical differences.

of physical mixing processes on the dynamics of $\mathrm{pH}$ and $p \mathrm{CO}_{2}$. Nonetheless, the water depth revealed smaller variation ranges at the IL site than the NS site in all seasons (Figures 2I-L), suggesting a weaker water exchange process and thus a potential higher control of metabolic activities in carbonate chemistry at the sheltered IL site. Additionally, as shown in Figure 5, the variations of DO saturation (green symbols) were generally in phase with temperature (red symbols) but out of phase with water depth (blue symbols) at the both sites, implying that factor(s) other than water exchange could also play an important role in regulating the variations of biogeochemical characteristics in the study area. From these lines of evidence, we suggest that the physical mixing processes and the diverse biogeochemical processes deriving from the different hydrodynamic regimes between the two sites could altogether cause the observed different behaviors in $\mathrm{pH}$ and $p \mathrm{CO}_{2}$ between the NS and IL sites.

\section{The Enhancement of Metabolic Carbonate Dissolution in the Inner Lagoon}

As revealed in the results, the $\mathrm{CO}_{2}$ dynamics at the NS site showed strong diel variation in all seasons (red squares in Figure 3), which was similar to the common pattern found in other seagrass meadows (Frankignoulle and Distèche, 1984; Gattuso et al., 1998; Bouillon et al., 2007; Turk et al., 2015; Ganguly et al., 2017; Cyronak et al., 2018; Berg et al., 2019; McCutcheon et al., 2019). In contrast, the unexpected high $\mathrm{pH}$ and low $p \mathrm{CO}_{2}$ values across a diel cycle were found repeatedly at the IL site (blue circles in Figure 3) in four different seasons. We suggest that the semienclosed setting of the IL may provide an ideal circumstance for sedimentary TA production through enhanced carbonate dissolution that could represent an important driver to form the observed unique diel pattern in carbonate chemistry at the IL site.

Previous studies have shown that seagrasses may induce carbonate sediment dissolution by the combined effect of OM being supplied and oxygen pumping via their roots and rhizomes, which may fuel OM respiration and thus $\mathrm{CO}_{2}$ release and a lower carbonate saturation state $(\Omega)$, consequently leading to carbonate mineral dissolution (Burdige and Zimmerman, 2002; Burdige et al., 2008). This process is often referred to as "metabolic carbonate dissolution" (Kindeberg et al., 2020), as represented in the following equations:

$$
\begin{aligned}
& \mathrm{CH}_{2} \mathrm{O}+\mathrm{O}_{2} \rightarrow \mathrm{CO}_{2}+\mathrm{H}_{2} \mathrm{O} \rightarrow \mathrm{H}_{2} \mathrm{CO}_{3} \\
& \mathrm{CaCO}_{3}+\mathrm{H}_{2} \mathrm{CO}_{3} \rightarrow \mathrm{Ca}^{2+}+2 \mathrm{HCO}_{3}{ }^{-}
\end{aligned}
$$

where $\mathrm{CH}_{2} \mathrm{O}$ represents a simplified formula for OM undergoing remineralization. The net reaction can therefore be described stoichiometrically as:

$$
\mathrm{CH}_{2} \mathrm{O}+\mathrm{O}_{2}+\mathrm{CaCO}_{3} \rightarrow \mathrm{Ca}^{2+}+2 \mathrm{HCO}_{3}^{-}
$$

which increases both the TA and DIC of the porewater with a ratio of $1: 1$.

We suggest that the "metabolic carbonate dissolution" can be stimulated in the seagrass meadows of the IL, due to several auspicious conditions. First, the confinement of the semienclosed IL may hamper seagrass detritus export to the adjacent open ocean and thus cause more OM to accumulate in the reef sediments at the IL site, as evidenced by the elevated TC and TN contents shown in Figures 4H,I. More OMs may fuel stronger aerobic and/or anaerobic respiration that can decrease carbonate saturation level, and thus drive carbonate dissolution. This explanation is further supported by the undersaturated values of $\Omega_{\mathrm{a}}(<1)$ and elevated levels of $\mathrm{Ca}^{2+}$ in the porewater at the IL site (Figures 4E,F). Second, the relatively calm hydrodynamic environment at the IL site could also be favorable for fine-grained sediment accumulation as shown in Figure 4G, which may facilitate DIC and TA production 

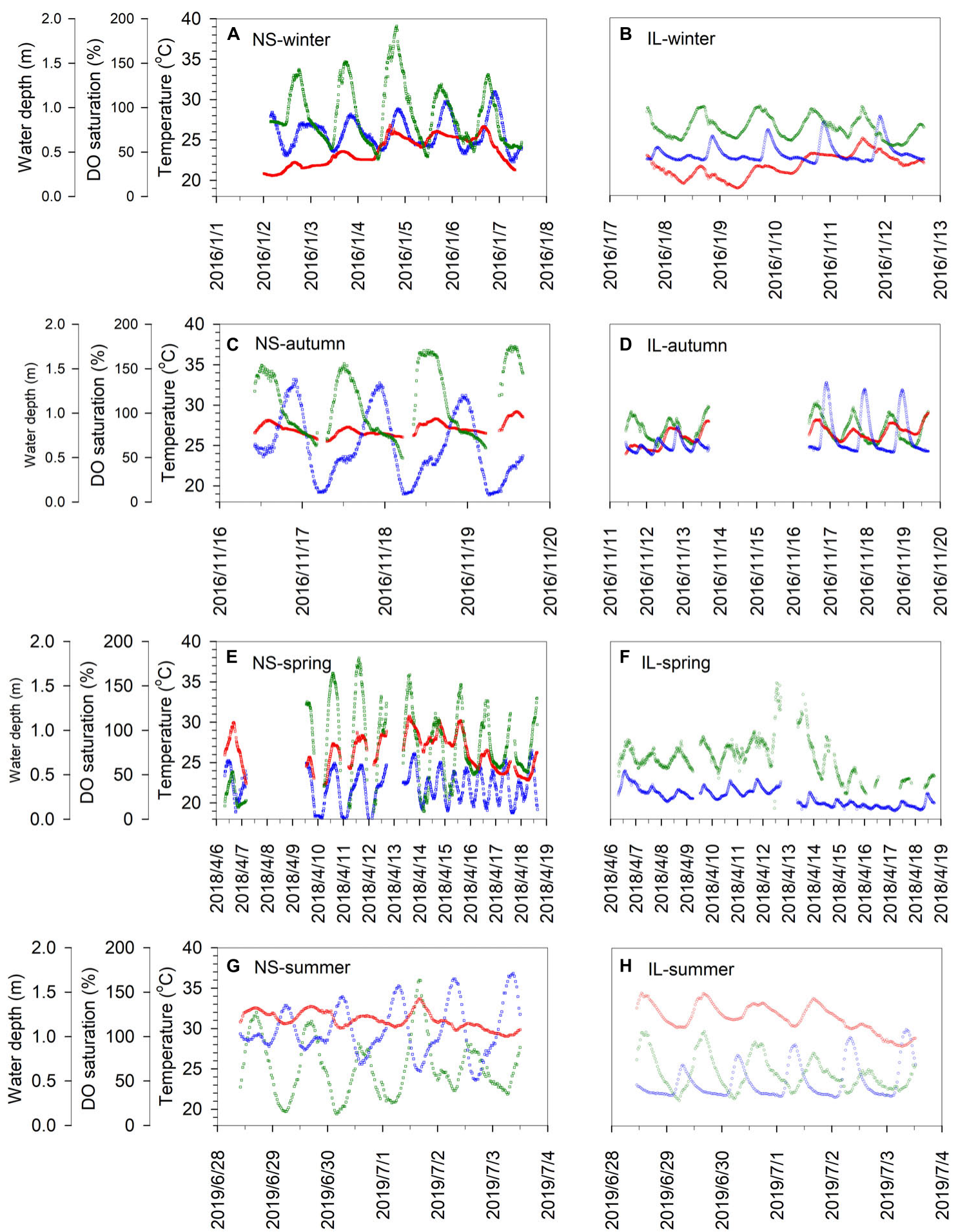

FIGURE 5 | Seasonal time-series observations of temperature (red symbols), water depth (red symbols), and DO saturation (red symbols) in the inner lagoon (IL, right panels; $\mathbf{B}, \mathbf{D}, \mathbf{F}, \mathbf{H})$ and on the northern shore (NS, left panels; $\mathbf{A}, \mathbf{C}, \mathbf{E}, \mathbf{G})$ of Dongsha Island.

in various ways. For instance, fine-grained sediments can provide greater available reactive surface area for all of the metabolic processes. Moreover, the overall finer-grained sediments may result in a lower permeability that may reduce oxygen penetration and thus favor the occurrence of anaerobic OM remineralization, which could also contribute to DIC and TA production ( $\mathrm{Hu}$ and Cai, 2011; Reithmaier et al., 2021). Finally, the less-energetic hydrodynamic and low sediment permeability may collectively 
result in a longer porewater residence time and thus allow for the buildup of DIC and TA in the porewater at the IL site as shown in Figures 4A,B. Besides, previous studies have indicated the occurrence of carbonate mineral reprecipitation along with dissolution in sediments at dense seagrass site (Hover et al., 2001; Hu and Burdige, 2007). Though we cannot be sure whether the coupled carbonate dissolution and reprecipitation occurred at our study sites due to the limitation of data, we think that carbonate mineral reprecipitation could be more likely to take place in the porewater at the NS site compared to the Il site, because the former was supersaturated but the latter was undersaturated with respect to aragonite (Figure 4E), and this could also partially explain why TA and DIC in the porewater at the NS site were lower than the IL site. Nevertheless, we suggest that the role of coupled carbonate dissolution and reprecipitation in regulating $\mathrm{CO}_{2}$ system in porewater of seagrass meadows remains to be further examined.

Although the "metabolic carbonate dissolution" can simultaneously release DIC and TA in the porewater (reaction 3 ), which can then be exported to the overlying water column via the advection induced by tide, current, and wave actions and/or the diffusion driven by the chemical gradient between the SWI. The exported DIC can be taken up again through the high productivity of the seagrasses, whereas photosynthesis cannot consume TA. Consequently, the TA exported from porewater can remain in the overlying water column. The confinement of the IL site may also hinder water exchange with the adjacent open ocean, thus providing another favorable circumstance for the accumulation of the sedimentary generated TA in the overlying water column. Thermodynamically, TA increases with a constant DIC may not only drive $\mathrm{pH}$ increases and $p \mathrm{CO}_{2}$ decreases in seawater but also enhance their buffer capacities, which could at least partially explain why a weak diel pattern with an extremely high $\mathrm{pH}$ and low $\mathrm{pCO}_{2}$ across a diurnal cycle was seasonally observed within the seagrass meadows at the IL site.

It is worth noting that the studied seagrass meadows are not totally isolated from the Dongsha Atoll, where the living coral reef flat encircles the lagoon (Figure 1). Depending on the direction and strength of water exchange, the $\mathrm{CO}_{2}$ system in individual ecosystem can affect each other (Sippo et al., 2016; Saderne et al., 2019a). In fact, a recent study has shown that TA in the Dongsha Atoll lagoon is depleted relative to the offshore water due to calcification therein (Fan et al., 2021). Thus, if the produced TA through the aforementioned processes in seagrass meadows can be exported to the adjacent Dongsha Atoll lagoon, it could at least partially offset the TA depletion from calcification, and thus could be beneficial for the associated coral reefs facing future OA. However, quantifying the export of TA by benthic ecosystems requires hydrological and bathymetrical data, and models (Saderne et al., 2019a), which are not available for us now. Nevertheless, we highlight the importance of quantifying the hydrodynamics-induced TA and DIC exchanges between coastal ecosystems, which could be crucial to better understand how costal blue carbon ecosystems could contribute to the growth of downstream reefs (Sippo et al., 2016; Saderne et al., 2019a).

\section{Relationship Between Normalized Total Alkalinity and Normalized Dissolved Inorganic Carbon}

Besides organic and $\mathrm{CaCO}_{3}$ metabolisms associated to the plant themselves, and the related flora and fauna, aerobic and anaerobic processes in sediments may also affect seawater carbonate chemistry in seagrass meadows (Chou et al., 2018; Saderne et al., 2019a). Generally, the stoichiometry of the relationship between

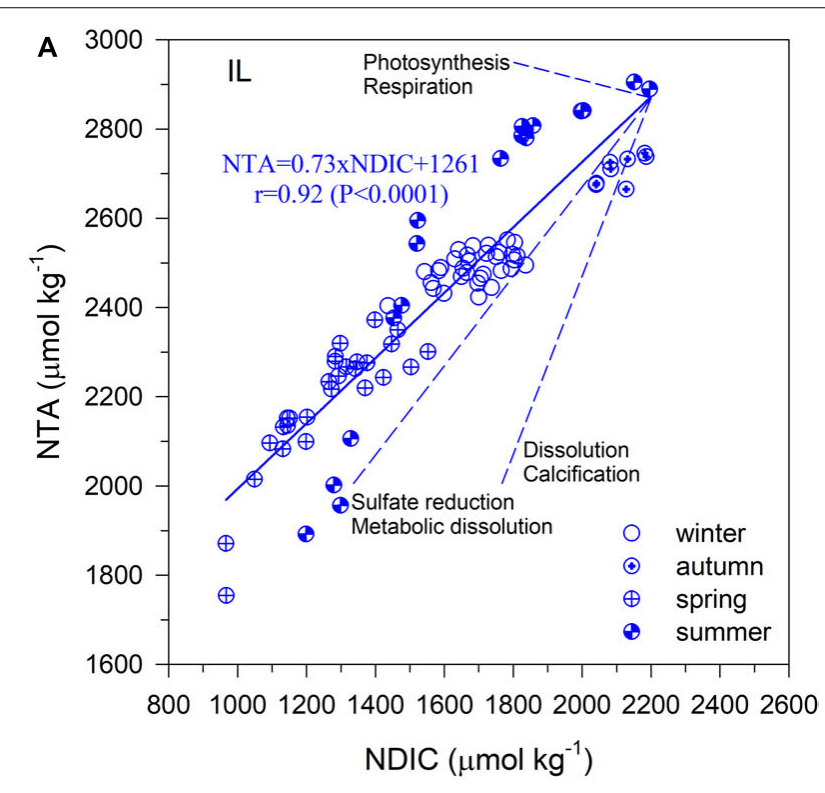

B

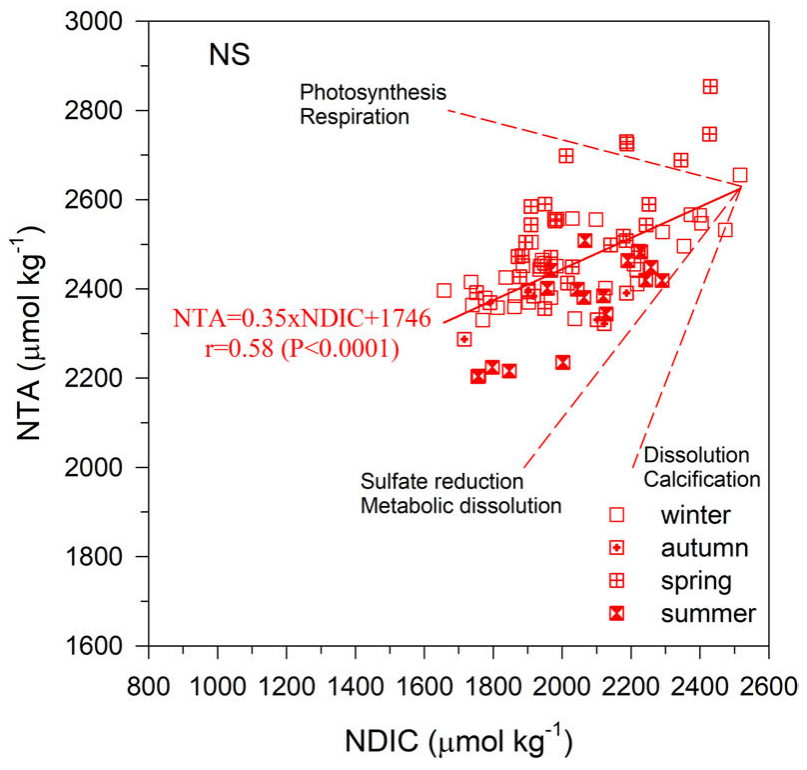

FIGURE 6 | Covariation in NTA and NDIC for the water samples collected in (A) the inner lagoon (IL), and on (B) the northern shore (NS) of Dongsha Island. The solid lines represent the regression lines. The dotted lines represent the stoichiometric ratios of major biogeochemical processes: photosynthesis/respiration, calcification/dissolution, metabolic dissolution, and sulfate reduction. 
NTA and NDIC is used to interpret the dominant processes driving the carbonate system because the relative variation in TA and DIC follows a well-established stoichiometric ratio that is specific to the respective processes, where the ratios for organic metabolism (photosynthesis/respiration), carbonate metabolism (calcification/carbonate dissolution), and net "metabolic carbonate dissolution" (reaction 3) are $0 / 1,2 / 1$, and 1/1, respectively ( $\mathrm{Hu}$ and Cai, 2011; Rassmann et al., 2020). In addition to organic and $\mathrm{CaCO}_{3}$ metabolisms, a series of redox reactions in sediments, including denitrification, manganese reduction, iron reduction, and sulfate reduction (SR), may also play an important role in regulating the carbonate system. As sulfate is far more abundant than other oxidant in seawater, SR is often the dominant redox reaction in sediment with a relative variation ratio in TA and DIC of $1 / 1$ (Burdige, 2011), as denoted in the following equation:

$$
2 \mathrm{CH}_{2} \mathrm{O}+\mathrm{SO}_{4}{ }^{2-} \rightarrow 2 \mathrm{HCO}_{3}^{-}+\mathrm{H}_{2} \mathrm{~S}
$$

Figure 6 shows the covariation in NTA and NDIC for the water samples collected at the IL (Figure 6A) and NS (Figure 6B) sites. As shown, the slopes of NTA vs. NDIC of the regression lines for the IL and NS are 0.73 and 0.35 , respectively. Neither slope follows the specific ratio of any single process, implying that organic and $\mathrm{CaCO}_{3}$ metabolisms, and SR may collectively control TA and DIC variations at the IL and NS sites (Drupp et al., 2016). Though partitioning between the causes of the observed $\mathrm{CO}_{2}$ system variation is difficult, the higher slope suggests that the "metabolic carbonate dissolution" and/or SR could play a more

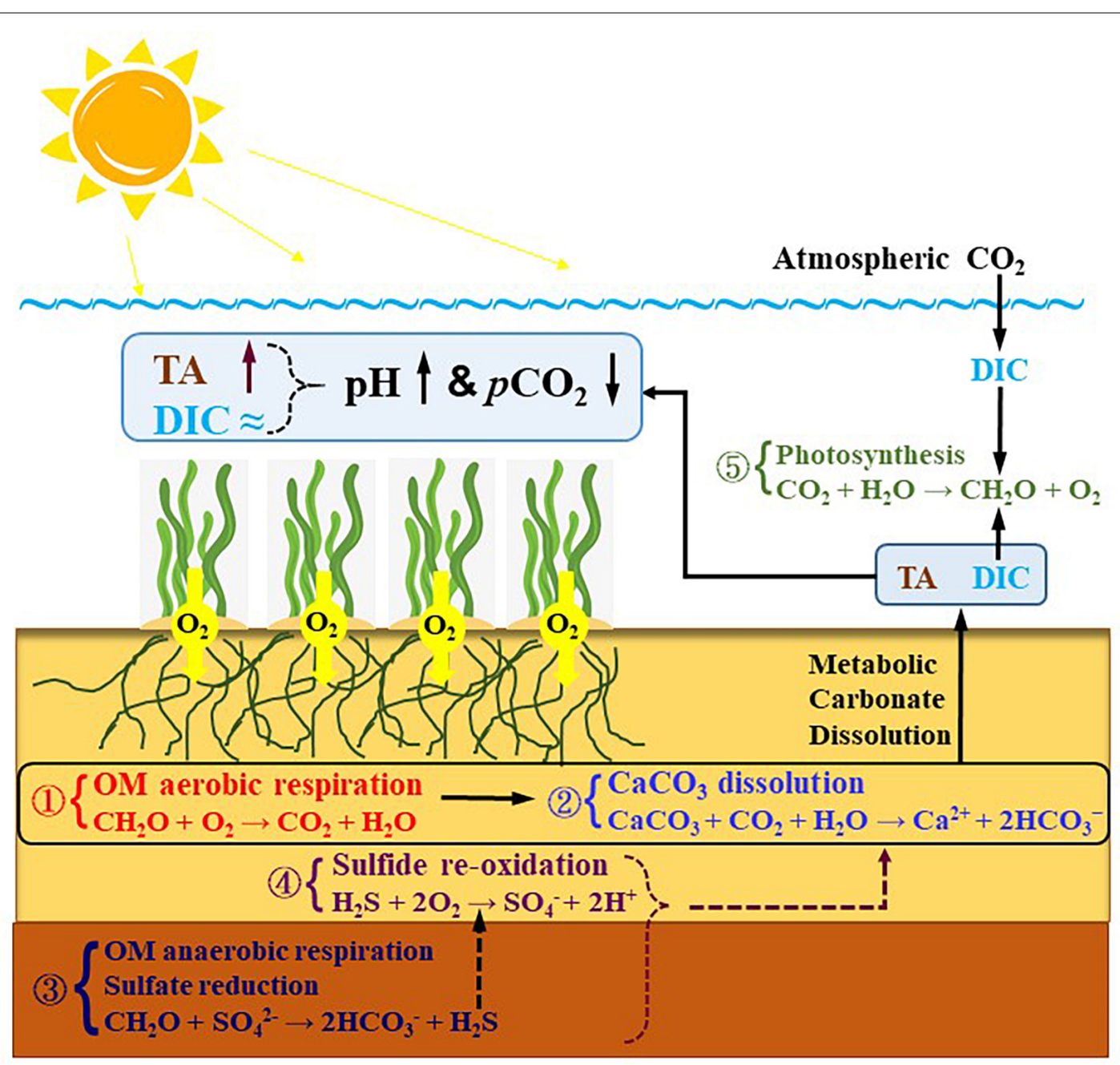

FIGURE 7 | A tentative conceptual model explaining the enhancement of metabolic carbonate dissolution in the seagrass meadows of the inner lagoon on Dongsha Island. First, the elevated OM loading may fuel aerobic respiration (reaction 1) that can produce DIC and reduce carbonate saturation level leading to carbonate dissolution (reaction 2) and thus TA and DIC production, i.e., the "metabolic carbonate dissolution." Secondly, presuming that sulfate reduction (reaction 3) would take place in the deeper anoxic layer and the resulting sulfide subsequently re-oxide to sulfate (reaction 4) in the shallow oxic layer, the whole process can serve as a proton shuttle that can also facilitate carbonate dissolution. Finally, the sedimentary exported DIC can be taken up again by the high productivity of the seagrasses, whereas photosynthesis (reaction 5) cannot consume TA. Consequently, the sedimentary exported TA can remain in the overlying seawater, and thereby forming a unique diel pattern with extremely high $\mathrm{pH}$ and low $\mathrm{pCO}_{2}$ values across a diel cycle. 
important role in regulating carbonate chemistry at the IL site compared to the NS site.

Besides, it is worth noting that although we did not measure sulfate and sulfide in this study, the presence of SR in the sediments at the IL site is to be expected, providing that the favorable conditions of elevated OM loading and finer MGS were observed. If $\mathrm{SR}$ takes place, the resulting $\mathrm{H}_{2} \mathrm{~S}$ in ironpoor carbonate sediments could easily re-oxidize to sulfate within the shallow oxic layer. This process can serve as a proton shuttle to facilitate carbonate dissolution (Ku et al., 1999; Burdige et al., 2008; Drupp et al., 2016), as represented in the following equations:

$$
\begin{aligned}
& \mathrm{H}_{2} \mathrm{~S}+2 \mathrm{O}_{2} \rightarrow \mathrm{SO}_{4}^{2-}+2 \mathrm{H}^{+} \\
& \mathrm{CaCO}_{3}+\mathrm{H}^{+} \rightarrow \mathrm{Ca}^{2+}+\mathrm{HCO}_{3}^{-}
\end{aligned}
$$

Therefore, SR coupled to sulfide re-oxidation may represent another potential pathway to stimulate carbonate dissolution at the IL site. Nonetheless, the net impact of reactions 46 on carbonate system are indistinguishable from "metabolic carbonate dissolution" denoted by reaction 3 . Thus, more studies of detailed porewater chemistry in sulfate and sulfide as well as pyrite formation in sediments will be needed to further clarify the potential contribution of SR to TA production (Reithmaier et al., 2021). In fact, the partitioning between the sources of TA from $\mathrm{CD}$ and SR remains a scientific and analytical challenge to date in blue carbon studies (Saderne et al., 2020).

In summary, based on these discussions, we tentatively proposed a conceptual model summarizing the potential processes controlling TA and DIC dynamics in the IL in Figure 7, which may collectively enhance sedimentary $\mathrm{CaCO}_{3}$ dissolution and thus TA production.

\section{The Potential Role of Organic Alkalinity}

In seawater dissolved organic acids produced by organic metabolism dissociate into conjugate bases, which may react with protons during seawater titration and thereby contribute to the

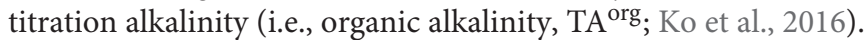
A number of studies have shown that $\mathrm{TA}^{\text {org }}$ can be significant in productive coastal environments (Cai et al., 1998; Kulinski et al., 2014). Therefore, $\mathrm{TA}^{\text {org }}$ could also play a non-ignorable role in regulating carbonate chemistry in seagrass meadows. TA ${ }^{\text {org }}$ has been measured indirectly as a difference between TA measured by direct titration ( $\mathrm{TA}^{\text {meas }}$ ) and TA calculated ( $\left.\mathrm{TA}^{\mathrm{cal}}\right)$ from the measured DIC and $\mathrm{pH}$ (i.e., $\Delta \mathrm{TA}=\mathrm{TA}^{\text {meas }}-\mathrm{TA}^{\text {cal }}$; Yang et al., 2015). Since the $\mathrm{CO}_{2}$ system was overdetermined in the present study, we can determine $\mathrm{TA}^{\text {org }}$ by calculating $\triangle \mathrm{TA}$.

Figure 8 shows the comparison of the $\mathrm{TA}^{\text {meas }}$ and $\mathrm{TA}^{\mathrm{cal}}$ at the NS and IL site, in which the difference between the data points and the 1:1 line $(\triangle \mathrm{TA})$ denotes $\mathrm{TA}^{\mathrm{org}}$. As shown, the $\mathrm{TA}^{\text {meas }}$ and $\mathrm{TA}^{\mathrm{cal}}$ generally follow the 1:1 line in winter, autumn and summer at the NS site, and in winter and autumn at the IL site, suggesting no significant $\mathrm{TA}^{\text {org }}$ production during these periods. In contrast, the $\mathrm{TA}^{\text {meas }}$ are apparently higher than $\mathrm{TA}^{\mathrm{cal}}$ in spring at the NS site, and in spring and summer at the IL site, indicating substantial $\mathrm{TA}^{\text {org }}$ production during these periods. The higher $\mathrm{TA}^{\text {org }}$ production in spring and summer at the IL

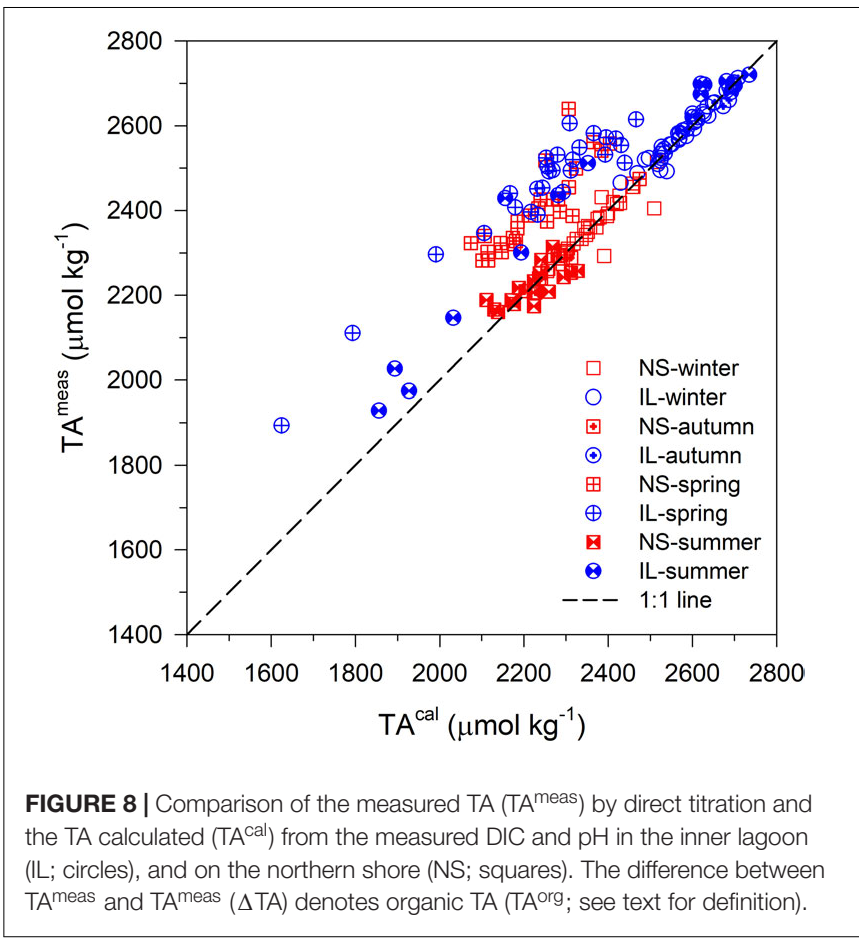

site could be associated with the more active organic metabolism in seagrass meadows during the warm seasons (Huang et al., 2015). Moreover, it is worth noting that spring and summer are also the only two seasons when the median of $\mathrm{TpCO}$ is significant lower at the IL site compared to the NS site according to a W-R ANOVA analysis (Table 1). Also, at the NS site, when $\mathrm{TA}^{\text {org }}$ production was higher in spring, the amplitudes of daily variations in $\mathrm{pH}$ and $\mathrm{pCO}_{2}$ appear to be smaller than the other seasons (Figures $\mathbf{3 A - H}$ ). These results imply that in addition to the aforementioned processes in Sections "The Enhancement of Metabolic Carbonate Dissolution in the Inner Lagoon" and "Relationship Between Normalized Total Alkalinity and Normalized Dissolved Inorganic Carbon," TA ${ }^{\text {org }}$ production could also play a non-ignorable role in regulating carbonate chemistry in seagrass meadows, especially during the warm seasons. Therefore, we suggest that $\mathrm{TA}^{\text {org }}$ production could be a potentially interesting and relevant research topic in studying $\mathrm{CO}_{2}$ system in costal blue carbon ecosystems, which needs more research.

\section{CONCLUDING REMARKS}

To the best of our knowledge, the seasonal recurrence of high $\mathrm{pH}$ and low $\mathrm{pCO}_{2}$ values across a diel cycle within seagrass meadows, such as those at the IL site on Dongsha Island, has never been reported in other marine ecosystems. We suggest that this unique diel pattern in carbonate chemistry could be associated with the semienclosed nature of the IL site, including, higher OM loading, finer-grained sediment, smaller sediment permeability and longer residence time of the porewater, that may stimulate both aerobic and anaerobic respiration leading to $\mathrm{CaCO}_{3}$ dissolution and thus TA production. Overall, our 
results demonstrate that $\mathrm{CaCO}_{3}$ dissolution in vegetated reef sediments can be enhanced in a semienclosed environmental setting. Most importantly, the present study provides the first observational evidence showing that the intense mechanistic coupling between metabolic processes and carbonate dissolution in seagrass meadows in reef sediment with a confinement setting may create a localized buffering effect against $\mathrm{OA}$ and a strong $\mathrm{CO}_{2}$ sink, and thus may provide a valuable theoretical proposition for conserving and restoring seagrass meadows as a promising strategy for climate change mitigation. We also highlight the importance in quantifying the hydrodynamicsinduced TA and DIC exchanges between coastal ecosystems, which could be crucial to better understand how costal blue carbon ecosystems could contribute to the growth of downstream reefs. Furthermore, we find that $\mathrm{TA}^{\text {org }}$ could play a non-ignorable role in regulating carbonate chemistry in seagrass meadows, and thus may be a potentially interesting and relevant research topic in studying $\mathrm{CO}_{2}$ system in costal blue carbon ecosystems. Finally, since the present work was not conducted over a single year, the observed seasonal variation could be also affected by inter-annual variability, more studies with better temporal coverage are still needed to further elucidate the potential impact of inter-annual variability in our findings.

\section{DATA AVAILABILITY STATEMENT}

The datasets presented in this study can be found in online repositories. The names of the repository/repositories

\section{REFERENCES}

Baldry, K., Saderne, V., McCorkle, D. C., Churchill, J. H., Agusti, S., and Duarte, C. M. (2020). Anomalies in the carbonate system of Red Sea coastal habitats. Biogeosciences 17, 423-439. doi: 10.5194/bg-17-423-2020

Barrón, C., Duarte, C. M., Frankignoulle, M., and Borges, A. V. (2006). Organic carbon metabolism and carbonate dynamics in a Mediterranean seagrass (Posidonia oceanica) meadow. Estuaries Coast. 29, 417-426. doi: 10.1007/ bf02784990

Berg, P., Delgard, M. L., Polsenaere, P., McGlathery, K. J., Doney, S. C., and Berger, A. C. (2019). Dynamics of benthic metabolism, O2, and pCO2 in a temperate seagrass meadow. Limnol. Oceanogr. 64, 2586-2604. doi: 10.1002/lno.11236

Blott, S. J., and Pye, K. (2001). GRADISTAT: a grain size distribution and statistics package for the analysis of unconsolidated sediments. Earth Surf. Process Landf. 26, 1237-1248. doi: 10.1002/esp.261

Bouillon, S., Dehairs, F., Velimirov, B., Abril, G., and Borges, A. V. (2007). Dynamics of organic and inorganic carbon across contiguous mangrove and seagrass systems (Gazi Bay, Kenya). J. Geophys. Res. Biogeosci. 112:G02018.

Burdige, D. J. (2011). "Estuarine and coastal sediments-coupled biogeochemical cycling," in Treatise on Estuarine and Coastal Science, eds R. Laane and J. J. Middelburg (Amsterdam: Elsevier Inc.), 279-316. doi: 10.1016/b978-0-12374711-2.00511-8

Burdige, D. J., and Zimmerman, R. C. (2002). Impact of sea grass density on carbonate dissolution in Bahamian sediments. Limnol. Oceanogr. 47, 17511763.

Burdige, D. J., Zimmerman, R. C., and Hu, X. P. (2008). Rates of carbonate dissolution in permeable sediments estimated from pore-water profiles: the role of sea grasses. Limnol. Oceanogr. 53, 549-565.

Cai, W.-J., Wang, Y., and Hodson, R. E. (1998). Acid-base properties of dissolved organic matter in the estuarine waters of Georgia, USA. Geochim. Cosmochim. Acta 62:4732483. and accession number(s) can be found below: The data used for this study are available at PANGEA (https://doi.org/10.1594/PANGEA.928748).

\section{AUTHOR CONTRIBUTIONS}

W-CC conceived the study, performed the field work, and wrote the manuscript. C-CY, Y-HC, and H-CT performed the field work and contributed to data collection and analysis. L-FF, $\mathrm{C}-\mathrm{CH}, \mathrm{W}-\mathrm{JH}, \mathrm{Y}-\mathrm{YS}$, and KS conceived the study and contributed to data interpretation. G-CG, H-YC, and C-KS contributed to the data collection and interpretation. All authors read and approved the final manuscript.

\section{FUNDING}

Funding was provided by the Ministry of Science and Technology of Taiwan grants \#107-2611-M-019-001-MY3 awarded to W-CC.

\section{ACKNOWLEDGMENTS}

We are grateful to the Dongsha Atoll Research Station, Dongsha Atoll National Park, and Coast Guard Administration for assistance in field sampling. We thank Rong-Wei Syu, HuiChuan Chu, and Kuan-Chieh Wu for their help with the field and laboratory work.

Challener, R. C., Robbins, L. L., and McClintock, J. B. (2016). Variability of the carbonate chemistry in a shallow, seagrass-dominated ecosystem: implications for ocean acidification experiments. Mar. Freshw. Res. 67, 163-172. doi: 10. $1071 / \mathrm{mf} 14219$

Chou, W.-C., Chu, H.-C., Chen, Y.-H., Syu, R.-W., Hung, C.-C., and Soong, K. (2018). Short-term variability of carbon chemistry in two contrasting seagrass meadows at Dongsha island: implications for $\mathrm{pH}$ buffering and $\mathrm{CO}_{2}$ sequestration. Estuar. Coast. Shelf Sci. 210, 36-44. doi: 10.1016/j.ecss.2018. 06.006

Chou, W.-C., Gong, G.-C., Yang, C.-Y., and Chuang, K.-Y. (2016). A comparison between field and laboratory $\mathrm{pH}$ measurements for seawater on the East China Sea shelf. Limnol. Oceanogr. Methods 14, 315-322. doi: 10.1002/lom3. 10091

Chou, W.-C., Liu, P.-J., Chen, Y.-H., and Huang, W.-J. (2020). Contrasting changes in diel variations of net community calcification support that carbonate dissolution can be more sensitive to ocean acidification than coral calcification. Front. Mar. Sci. 7:3. doi: 10.3389/fmars.2020.00003

Chou, W.-C., Sheu, D.-D., Chen, C.-T. A., Wang, S.-L., and Tseng, C.-M. (2005). Seasonal variability of carbon chemistry at the SEATS time-series site, northern South China Sea between 2002 and 2003. Terr. Atmospheric Ocean. Sci. 16, 445-465. doi: 10.3319/tao.2005.16.2.445(o)

Cyronak, T., Andersson, A. J., D’Angelo, S., Bresnahan, P., Davidson, C., Griffin, A., et al. (2018). Short-term spatial and temporal carbonate chemistry variability in two contrasting seagrass meadows: implications for $\mathrm{pH}$ buffering capacities. Estuaries Coast. 41, 1282-1296. doi: 10.1007/s12237-017-0356-5

Dickson, A. G., Sabine, C. L., and Christian, J. R. (2007). Guide to Best Practices for Ocean $\mathrm{CO}_{2}$ Measurements. Patricia Bay: North Pacific Marine Science Organization.

Drupp, P. S., De Carlo, E. H., and Mackenzie, F. T. (2016). Porewater $\mathrm{CO}_{2}$-carbonic acid system chemistry in permeable carbonate reef sands. Mar. Chem. 185, 48-64. doi: 10.1016/j.marchem.2016.04.004 
Duarte, C. M., Marba, N., Gacia, E., Fourqurean, J. W., Beggins, J., Barron, C., et al. (2010). Seagrass community metabolism: assessing the carbon sink capacity of seagrass meadows. Global Biogeochem. Cycles 24:GB4032.

Falter, J., and Sansone, F. (2000). Shallow pore water sampling in reef sediments. Coral Reefs 19, 93-97. doi: 10.1007/s003380050233

Fan, L.-F., Qiu, S.-Q., and Chou, W.-C. (2021). Carbonate chemistry of the Dongsha Atoll Lagoon in the northern South China Sea. Terr. Atmos. Ocean. Sci. 32, 399-409. doi: 10.3319/tao.2021.05.15.02

Folk, R. L. (1966). A review of grain-size parameters. Sedimentology 6, 73-93. doi: 10.1111/j.1365-3091.1966.tb01572.x

Fourqurean, J. W., Duarte, C. M., Kennedy, H., Marbà, N., Holmer, M., Mateo, M. A., et al. (2012). Seagrass ecosystems as a globally significant carbon stock. Nat. Geosci. 5, 505-509.

Frankignoulle, M., and Distèche, A. (1984). CO2 chemistry in the water column above a Posidonia seagrass bed and related air-sea exchanges. Oceanol. Acta 7 , 209-219.

Ganguly, D., Singh, G., Ramachandran, P., Selvam, A. P., Banerjee, K., and Ramachandran, R. (2017). Seagrass metabolism and carbon dynamics in a tropical coastal embayment. Ambio 46, 667-679. doi: 10.1007/s13280-0170916-8

Gattuso, J.-P., Frankignoulle, M., and Wollast, R. (1998). Carbon and carbonate metabolism in coastal aquatic ecosystems. Annu. Rev. Ecol. Evol. Syst. 29, 405-434.

Hendriks, I. E., Olsen, Y. S., Ramajo, L., Basso, L., Steckbauer, A., Moore, T. S., et al. (2014). Photosynthetic activity buffers ocean acidification in seagrass meadows. Biogeosciences 11, 333-346. doi: 10.1111/gcb.15594

Hover, V. C., Walter, L. M., and Peacor, D. R. (2001). Early marine diagenesis of biogenic aragonite and $\mathrm{Mg}$-calcite: new constrains from high-resolution STEM and AEM analysis of modern platform carbonate. Chem. Geol. 175, 221-248. doi: 10.1016/s0009-2541(00)00326-0

Howard, J. L., Creed, J. C., Aguiar, M. V. P., and Fouqurean, J. W. (2018). $\mathrm{CO}_{2}$ released by carbonate sediment production in some coastal areas may offset the benefits of seagrass "blue carbon" storage. Limnol. Oceanogr. 63, 160-172. doi: 10.1002/lno.10621

Hu, X., and Burdige, D. J. (2007). Enriched stable carbon isotopes in the pore waters of carbonate sediments dominated by seagrasses: evidence for coupled carbonate dissolution and reprecipitation. Geochim. Cosmochim. Acta 71, 129144. doi: 10.1016/j.gca.2006.08.043

$\mathrm{Hu}, \mathrm{X}$., and Cai, W. J. (2011). An assessment of ocean margin anaerobic processes on oceanic alkalinity budget. Global Biogeochem. Cycles 25:GB3003.

Huang, Y.-H., Lee, C.-L., Chung, C.-Y., Hsiao, S.-C., and Lin, H.-J. (2015). Carbon budgets of multispecies seagrass beds at Dongsha Island in the South China Sea. Mar. Environ. Res. 106, 92-102. doi: 10.1016/j.marenvres.2015.03.004

Hung, C.-C., and Gong, G.-C. (2010). POC/ ${ }^{234}$ Th ratios in particles collected in sediment traps in the northern South China Sea. Estuar. Coast. Shelf Sci. 88, 303-310.

Kindeberg, T., Bates, N. R., Courtney, T. A., Cyronak, T., Griffin, A., Mackenzie, F. T., et al. (2020). Porewater carbonate chemistry dynamics in a temperate and a subtropical seagrass system. Aquat. Geochem. 26, 375-399. doi: 10.1007/ s10498-020-09378-8

Ko, Y. H., Lee, K., Eom, K. H., and Han, I.-S. (2016). Organic alkalinity produced by phytoplankton and its effect on the computation of ocean carbon parameters. Limnol. Oceanogr. 61, 1462-1471. doi: 10.1002/lno.10309

Koch, E. W. (1994). Hydrodynamics, diffusion boundary layers and photosynthesis of the seagrasses Thalassia testudinum and Cymodocea nodosa. Mar. Biol. 118, 767-776. doi: 10.1007/bf00347527

Koch, E. W., Ackerman, J., van Keulen, M., and Verduin, J. (2006). “Fluid dynamics in seagrass ecology: from molecules to ecosystems," in Seagrasses: Biology, Ecology and conservation, eds A. W. D. Larkum, R. J. Orth, and C. M. Duarte (Berlin: Springer Verlag), 193-225. doi: 10.1007/1-4020-2983-7_8

Ku, T. C. W., Walter, L. M., Coleman, M. L., Blake, R. E., and Martini, A. M. (1999). Coupling between sulfur recycling and syndepositional carbonate dissolution: evidence from oxygen and sulfur isotope composition of pore water sulfate, South Florida Platform, USA. Geochim. Cosmochim. Acta 63, 2529-2546.

Kulinski, K., Schneider, B., Hammer, K., Machulik, U., and Schulz-Bull, D. (2014). The influence of dissolved organic matter on the acid-base system of the Baltic Sea. J. Mar. Syst. 132:1062115.
Lee, C.-L., Huang, Y.-H., Chung, C.-Y., Hsiao, S.-C., and Lin, H.-J. (2015). Herbivory in multi-species, tropical seagrass beds. Mar. Ecol. Prog. Ser. 525, 65-80. doi: 10.3354/meps11220

Maher, D. T., Call, M., Santos, I. R., and Sanders, C. J. (2018). Beyond burial: lateral exchange is a significant atmospheric carbon sink in mangrove forests. Biol. Lett. 14:20180200. doi: 10.1098/rsbl.2018.0200

Mair, P., and Wilcox, R. (2020). Robust statistical methods in R using the WRS2 package. Behav. Res. Methods 52, 464-488. doi: 10.3758/s13428-019-01 246-w

Manzello, D. P., Enochs, I. C., Melo, N., Gledhill, D. K., and Johns, E. M. (2012). Ocean acidification refugia of the Florida reef tract. PLoS One 7:e41715. doi: 10.1371/journal.pone.0041715

McCutcheon, M. R., Staryk, C. J., and Hu, X. P. (2019). Characteristics of the carbonate system in a semiarid estuary that experiences summertime hypoxia. Estuaries Coasts. 42, 1509-1523. doi: 10.1007/s12237-019-00588-0

Pacella, S. R., Brown, C. A., Waldbusser, G. G., Labiosa, R. G., and Hales, B. (2018). Seagrass habitat metabolism increases short-term extremes and longterm offset of $\mathrm{CO}_{2}$ under future ocean acidification. Proc. Natl. Acad. Sci. U.S.A. 115, 3870-3875. doi: 10.1073/pnas.1703445115

Pelletier, G., Lewis, E., and Wallace, D. (2011). CO2SYS. XLS: A Calculator for the $\mathrm{CO}_{2}$ System in Seawater for Microsoft Excel/VBA. Version 16. Washington, DC: Washington State Department of Ecology.

R Core Team (2021). R v4.1.1, Vienna, Austria. Available online at: https://www.Rproject.org/, (accessed August 10, 2021).

Rassmann, J., Eitel, E. M., Lansard, B., Cathalot, C., Brandily, C., Taillefert, M., et al. (2020). Benthic alkalinity and dissolved inorganic carbon fluxes in the Rhone River prodelta generated by decoupled aerobic and anaerobic processes. Biogeosciences 17, 13-33.

Reithmaier, G. M. S., Johnston, S. G., Junginger, T., Goddard, M. M., Sanders, C. J., Hutley, L. B., et al. (2021). Alkalinity production coupled to pyrite formation represents an unaccounted blue carbon sink. Global Biogeochem. Cycles 35:e2020GB006785.

Ruesink, J. L., Yang, S., and Trimble, A. C. (2015). Variability in carbon availability and eelgrass (Zostera marina) biometrics along an estuarine gradient in Willapa Bay, WA, USA. Estuaries Coasts. 38, 1908-1917. doi: 10.1007/s12237-0149933-Z

Saderne, V., Fusi, M., Thomson, T., Dunne, A., Mahmud, F., Roth, F., et al. (2020). Total alkalinity production in a mangrove ecosystem reveals an overlooked Blue Carbon component. Limnol. Oceanogr. Lett. 6, 61-67.

Saderne, V., Geraldi, N. R., Macreadie, P. I., Maher, D. T., Middelburg, J. J., Serrano, O., et al. (2019b). Role of carbonate burial in blue carbon budgets. Nat. Commun. 10:1106.

Saderne, V., Baldry, K., Anton, A., Agustí, S., and Duarte, C. M. (2019a). Characterization of the CO2 system in a coral reef, a seagrass meadow, and a mangrove forest in the central Red Sea. J. Geophys. Res. Oceans 2, 1-16.

Semesi, I. S., Beer, S., and Bjork, M. (2009). Seagrass photosynthesis controls rates of calcification and photosynthesis of calcareous macroalgae in a tropical seagrass meadow. Mar. Ecol. Prog. Ser. 382, 41-47.

Sippo, J. Z., Maher, D. T., Tait, D. R., Holloway, C., and Santos, I. R. (2016). Are mangroves drivers or buffers of coastal acidification? Insights from alkalinity and dissolved inorganic carbon export estimates across a latitudinal transect. Global Biogeochem. Cycles 30, 753-766. doi: 10.1002/2015gb00 5324

Su, C.-K., and Ho, C.-C. (2019). Online profiling of living rat brain extracellular $\mathrm{pH}$ using a $\mathrm{pH}$-dependent solid phase extraction scheme coupled with microdialysis sampling and inductively coupled plasma mass spectrometry. Anal. Chim. Acta 1055, 36-43. doi: 10.1016/j.aca.2018.12.020

Tseng, C. M., Wong, G. T. F., Chou, W. C., Lee, B. S., Sheu, D. D., and Liu, K. K. (2007). Temporal variations in the carbonate system in the upper layer at the SEATS station. Deep-Sea Res. II 54, 1448-1468. doi: 10.1016/j.dsr2.2007. 05.003

Turk, D., Yates, K. K., Vega-Rodriguez, M., Toro-Farmer, G., L'Esperance, C., Melo, N., et al. (2015). Community metabolism in shallow coral reef and seagrass ecosystems, lower Florida Keys. Mar. Ecol. Prog. Ser. 538, 35-52. doi: 10.3354/ meps 11385

Unsworth, R. K. F., Collier, C. J., Henderson, G. M., and McKenzie, L. J. (2012). Tropical seagrass meadows modify seawater carbon chemistry: implications 
for coral reefs impacted by ocean acidification. Environ. Res. Lett. 7:024026. doi: $10.1088 / 1748-9326 / 7 / 2 / 024026$

Waldbusser, G. G., and Salisbury, J. E. (2014). Ocean acidification in the coastal zone from an organism's perspective: multiple system parameters, frequency domains, and habitats. Ann. Rev. Mar. Sci. 6, 221-247. doi: 10.1146/annurevmarine-121211-172238

Yang, B., Byrne, R. H., and Lindemuth, M. (2015). Contributions of organic alkalinity to total alkalinity in coastal waters: a spectrophotometric approach. Mar. Chem. 176, 199-207. doi: 10.1016/j.marchem.2015.09.008

Conflict of Interest: The authors declare that the research was conducted in the absence of any commercial or financial relationships that could be construed as a potential conflict of interest.
Publisher's Note: All claims expressed in this article are solely those of the authors and do not necessarily represent those of their affiliated organizations, or those of the publisher, the editors and the reviewers. Any product that may be evaluated in this article, or claim that may be made by its manufacturer, is not guaranteed or endorsed by the publisher.

Copyright (c) 2021 Chou, Fan, Yang, Chen, Hung, Huang, Shih, Soong, Tseng, Gong, Chen and Su. This is an open-access article distributed under the terms of the Creative Commons Attribution License (CC BY). The use, distribution or reproduction in other forums is permitted, provided the original author(s) and the copyright owner(s) are credited and that the original publication in this journal is cited, in accordance with accepted academic practice. No use, distribution or reproduction is permitted which does not comply with these terms. 